Article

\title{
Sustainability Assessment of Household Waste Based Solar Control Devices for Workshops in Primary Schools
}

\author{
Oriol Pons ${ }^{1, * \mathbb{D}}$, Saeid Habibi ${ }^{1}$ and Diana Peña ${ }^{2}$ \\ 1 Department of Architectural Technology, UPC, Av. Diagonal 649, 08028 Barcelona, Spain; \\ saeid.habibi@upc.edu \\ 2 Structural Morphology in Architecture (SMiA), UPC, C/Pere Serra 1-15, Sant Cugat del Vallès, \\ 08173 Barcelona, Spain; dianamaritzap@yahoo.com \\ * Correspondence: oriol.pons@upc.edu; Tel.: +34-934-016-391
}

Received: 10 October 2018; Accepted: 2 November 2018; Published: 6 November 2018

check for updates

\begin{abstract}
Part of the large amounts of waste generated by human activities could have a second use while solving social problems. In this sense, the authors are carrying out a research project involving the participative development of innovative solar control devices integrated into school architecture using household waste. In general, the objectives of this research project are to: (a) optimize pupils' learning process by improving lighting and thermal comfort levels and (b) reduce the generation of Spanish household waste by reusing part of it and increase the teaching community's awareness about this waste. This research article reports on the steps taken to achieve these objectives by characterizing the most sustainable types of the waste-based solar control device. In this sense, this research paper defines and applies a new methodology which combines General Morphology Analysis (GMA), a new tool based on The Integrated Value Model for Sustainable Assessment and Focus groups. First, up to 96 different types of solar control devices composed of household waste have been defined using GMA and, second, these 96 types and conventional roller shutters have been assessed using this new tool. Based on these article results, one of the best alternatives has been prototyped during an initial workshop.
\end{abstract}

Keywords: household waste; sustainability; general morphology analysis; multi-criteria decision making; MIVES; focus groups; participatory workshops; solar control; primary education

\section{Introduction}

Global cities waste generation is expected to increase to 2.2 billion tons per year by 2025 [1]. These urban areas create the largest waste share, which is known as municipal solid waste (MSW-Appendix E presents a complete list of abbreviations) [2]. MSW is composed of ordinary daily waste and can be divided up as: (a) "household waste" and (b) waste produced during all the other activities within the city. MSW pollutes the environment, increases toxicity and worsens health [3]. Therefore, most governments and municipalities, among them Spanish entities, are looking for the best waste management mechanisms to deal with MSW [4]. In this sense, the European waste directive defines a waste hierarchy which includes these five options: (Op1) prevention; (Op2) reuse; (Op3) recycling; (Op4) recovery; and (Op5) disposal [5]. Op1 is crucial because it reduces waste generation by increasing producer and consumer's awareness with initiatives such as workshops [6] and educational activities [7]. Op2 is important because it gives a second use to waste and, in consequence, saves it from the waste cycle and reduces the final dumped waste.

In the history of architecture, there are numerous examples of reusing household waste as building components. At the end of the nineteenth century, Antoni Gaudí used broken dishes and bottles for 
façade cladding [8]. In the early twentieth century several houses were built using glass bottles in North America desert mining towns [9]. From the early 2000s, several walls were constructed using plastic bottles as well [10]. There are also several recent projects on structures composed of plastic bottles [11] and experiences within the Do-it-Yourself social movement [12].

Numerous previous studies and practices about students' learning processes have proven that in school buildings, providing thermal comfort and air quality are crucial [13] as well as natural lighting and visual comfort [14]. The Heschong Mahone group [15] illustrated daylighting and its extension as the main support requirements for studying with $20 \%$ progress in classrooms with most daylighting and biggest windows. Barrett et al., [16] by assessing the effects of physical features on 3766 pupils' learning progress in 153 classrooms, demonstrated that Naturalness design principle, comprised by light, sound, temperature, air quality, and links to nature is accountable for $50 \%$ of the impact on learning progress, with the other two design principles, Individualization and Simulation, accounting for roughly a quarter each.

Also, it has been reported in numerous Spanish school buildings which could not satisfy the current indoor environmental regulations and requirements for school buildings due to their conformity with obsolete standards, guidelines, and criteria or they are buildings for other purposes converted to schools [17]. These problems have been revealed following the construction of hundreds of schools in limited timeframes and tight budgets because of urgent needs for educational centers in recent years [18] and developed into a serious uncomfortableness issues in June 2017 in hundreds of schools due to extremely hot conditions with abnormally high temperatures in eight Autonomous Communities [19]. This challenge and its effects on students' academic progress became the focus of journalistic reports as a serious social impact during 2017 as shown in Table 1.

Table 1. News articles about the heating problems in 2016 and 2017 in most affected Spanish territories.

\begin{tabular}{|c|c|c|c|c|c|}
\hline \multirow{2}{*}{$\begin{array}{c}\text { Spanish Autonomous } \\
\text { Community }\end{array}$} & \multicolumn{2}{|c|}{ Most Read Newspaper } & \multirow{2}{*}{$\begin{array}{c}2017 \\
\text { General } \\
\text { News }\end{array}$} & \multirow{2}{*}{$\begin{array}{c}2017 \\
\text { Specific } \\
\text { News }\end{array}$} & \multirow{2}{*}{$\begin{array}{c}2016 \\
\text { Genera } \\
\text { News }\end{array}$} \\
\hline & Name & Website & & & \\
\hline Andalusia & Ideal & www.ideal.es & 21 & 8 & 0 \\
\hline Catalonia & La Vanguardia & www.lavanguardia.com & 23 & 2 & 4 \\
\hline $\begin{array}{l}\text { Community of Madrid, } \\
\text { Castilla-La Mancha }\end{array}$ & El País & www.politica.elpais.com & 13 & 1 & 1 \\
\hline Castile and León & $\begin{array}{l}\text { El Norte de } \\
\text { Castilla }\end{array}$ & www.elnortedecastilla.es & 5 & 3 & 1 \\
\hline Aragon & Heraldo & www.heraldo.es & 19 & 5 & 3 \\
\hline Extremadura & Región digital & www.regiondigital.com & 16 & 2 & 1 \\
\hline
\end{tabular}

Legend: Most read newspaper: the most read newspaper in each autonomous community from Spanish National Statistics Institute, available in http:/ / www.ine.es/; 2017 general news: Number of different articles published in June 2017 related to high temperatures problems in general; 2017 specific news: Number of different articles published in June 2017 related to high-temperature problems in school buildings; 2016 general news: Number of different articles published in June 2016 related to high-temperature problems in general.

This problem was caused mainly due to the low performance or non-existence of natural light control devices, with the subsequent inability to properly control these two effects by sun radiation on window panes: (a) the amount of light that enters into a classroom, and (b) the thermal gains due to the greenhouse effect. For example, interior devices control this second effect less successfully. If these devices are properly designed, they can control these two effects, both of which can be desired or undesired [20] depending on the educational requirements. On the other hand, most Spanish schools do not have air conditioning (AC) systems, which could be one of the future solutions for these schools. However, if standard AC equipment were installed, the energy impact of these buildings would increase [21]. 
By incorporating renewable energy systems in these solar control devices, schools can provide awareness and learning activities related to the advantages of renewable energies [22] which can be explained or observed during workshops for, and usage by, these devices. Reviewing renewable energy systems incorporated in solar control devices, this research project studied 30 existing representative buildings constructed from the late 1990s to present. Most buildings studied have Photovoltaic (PV) systems incorporated in non-movable solar control devices. Few of them are educational buildings such as Voorschoten British School [23].

In this sense, this article is part of a broader project that aims to find the best waste based solar control device to solve the aforementioned abusive solar thermal and lighting gains during workshops with primary students and teachers. In consequence, this device has to be the most sustainable alternative from overall sustainability dimensions including economic, environmental and social issues [24,25]. Therefore, the main objectives of this research paper are: (a) develop a new methodology able to define all the feasible alternatives within the boundaries set by this study and assess the sustainability of these alternatives; (b) apply this methodology in order to find the most sustainable alternative within the guidelines set by this study; and (c) due to satisfaction gained from these first two objectives, develop a prototype the first version of the most sustainable solution for a specific workshop, school building, and its community.

\section{Methodology}

This research article has developed and applied a new methodology that combines General Morphology Analysis (GMA) [26], a new holistic Multi-Criteria Decision Making (MCDM) tool based on The Integrated Value Model for Sustainable Assessment (MIVES) [27,28] and Focus groups [29] in order to achieve the aforementioned objectives. Before applying this methodology, the boundaries of this specific study have been defined rigorously. This first step was carried out along with experts in architecture and education composed by: school directors and teachers, educational and energy department members, educational workshops experts and renewable energy experts, among others. After defining these boundaries, these experts designed an initial questionnaire for the schools included in the sample and the researchers analyzed their feedbacks.

\subsection{GMA to Define Feasible Alternatives}

GMA [30] was used to define all the appropriate solar control device alternatives considering the requirements in his specific study. To do so, the researchers first chose the main parameters for the solar control devices and the value range for these parameters; second researchers limited the relevant solution space by examining the internal relationships between parameters using Cross-Consistency Assessment (CCA) and a cross-impact matrix ensuring the consistency and coexistence of each possible pair. This analysis took into account logical contradictions, empirical constraints and normative constraints. Numerous research projects have previously used this method; for example, an application for designing a sustainable school [31]. GMA is a complex methodology which involves analyzing a wide range of organized samples of alternatives and it was chosen precisely in order to be able to take into account all feasible alternatives without missing any interesting options.

\subsection{MIVES to Assess the Sustainability of the Feasible Alternatives}

MIVES is a MCDM method that incorporates the value function concept in order to define specialized holistic sustainability evaluation tools to obtain global and partial satisfaction indexes [32,33]. Compared to other interesting MCDM for Architecture and Civil Engineering [34] and schools specifically [35], MIVES particular characteristics [27] made it the best method to develop a tool for this case study. To define this tool, the experts followed three phases: (a) determine the basic tree of sustainability requirements for the decision model composed by the most important and discriminative requirements, criteria and indicators for the case study, both quantitative and qualitative; (b) calibrate the value functions that will unify the scales and units of each indicator to a 0 to 1 satisfaction value; 
(c) assign the weight for each tree requirements component. These experts assigned weights using Analytic Hierarchy Process (AHP) [36] or direct assignation. This second direct method was for cases when the $100 \%$ weight had to be assigned between a maximum of 3 components. These workshops and AHP bring objectivity to the requirements tree. Figure 1 presents the sustainability requirements tree with its components and weights $\left(\lambda_{R i, k}\right)$.

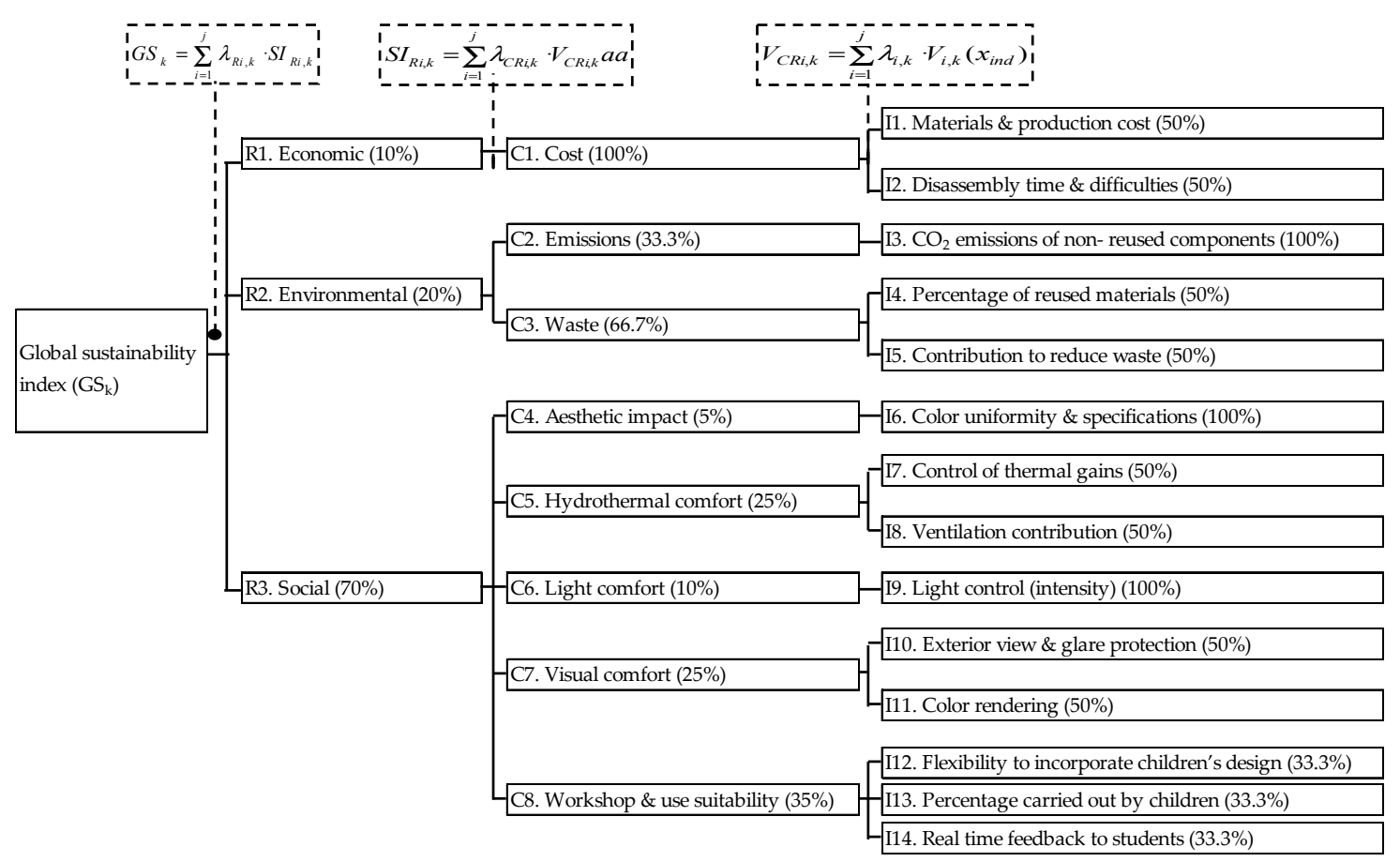

Figure 1. Diagram showing how the Global sustainability index $\left(G S_{k}\right)$ is obtained: adding up the three requirements satisfaction indexes $\mathrm{R} 1$ to $\mathrm{R} 3\left(S I_{R i, k}\right)$, which are obtained by adding up their own criteria $\mathrm{C} 1$ to $\mathrm{C} 8$ satisfaction indexes $\left(C I_{R i, k}\right)$, which are obtained by adding up their own indicator I1 to I14 adimensional aforementioned value functions satisfaction $\left(V_{i, k}\right)$; all of them corrected considering their own weights.

This project has a high social relevance that explains the particular weights and components of its tree. This is organized in the three main pillars of sustainability as requirements. The economic requirement has one criteria, cost. I1 assesses the materials and construction cost of non-reused components that are mainly joints and renewable energy devices because the reused components supply and assembly during workshops are considered free of cost. The time and difficulties of disassembling operations are considered in $\mathrm{I} 2$ because disassembly process will be carried out after finishing the school year and the reuse of connections and renewable energy devices is required. No maintenance costs are considered because solutions will be disassembled when the year is finished because part of these proposed educational objectives will be fulfilled during workshops each year. This requirement does not consider economic gains from the generation of energy because all alternatives will generate low electricity, which will run light-emitting diodes (LED) or fans and provide direct feedback to children's needs as previously explained. This occurs because this project focuses on children's learning and awareness about waste, as explained in detail in the introduction. Nevertheless, the schools will have economic gains from their energy savings and these gains could increase if the schools participate in programs such as Euronet 50/50 [37].

The environmental requirement assesses emissions and waste. Energy consumption of non-reused components has not been considered as an exclusive indicator but covered by $\mathrm{I}_{3} \mathrm{CO}_{2}$ emissions. This is the case because these components' energy consumption tendency is similar to emissions [18]. In consequence, emissions weights have been assigned considering the importance of both. Energy indicators such as thermal storage and passive systems are not considered because they have low 
viability in the alternatives and are already assessed in control of thermal gains. I4 assesses the percentage of reused materials in the whole alternative and I5 assesses how important the reuse of the materials chosen is to reduce local and global waste production. Water consumption is unassessed due to its insignificant rate when compared to the water consumed in the Life Cycle Analysis of the building.

The social requirement assesses five important criteria. C4 assesses the color of the solution and its uniformity and fulfilment of architectural specifications. Aesthetic impact does not include architectural specifications or urban \& landscape integration because the solution is temporary. C5 assesses the solution capacity to control thermal gains and ventilation contribution taking into account the variability of weather conditions in the sample location. Humidity control has not been included because this has been considered beyond solar protection device requirements. Light comfort in C6 and 19 assesses the capacity of the solution to control the light intensity in lux considering the changing daily and seasonal situations and the changing inside necessities, from light demanding activities to darkness demanding activities. C7 assesses the visual comfort considering in I10 the solution capacity to offer both exterior view and glare protection depending on the requirements, and in I11 the color rendering of objects inside the classroom. C8 assesses the accuracy of the solution during the workshop and its final use. I12 assesses the flexibility to incorporate children's designs and creativity to the final solar control device, and I13 values the percentage of the assembly carried out by children during the complete assembly process. I14 assesses the ability of the device to give real-time feedback to students about the solar control device performance. For example, this occurs if the device produces energy that is consumed by a fan or a LED, which shows how much energy is produced to children in real time. Other social issues have not been assessed because researchers consider that they do not depend on the alternative but the subsequent design, organization and management of the workshop. This is the case of the assembly process of the devices during the workshop. This process will be based on the primary education curriculum [38] in order to increase children's awareness and learning achievements.

These 14 indicators have value functions based on MIVES [32] considered with satisfaction levels from 0 to 1 and depend on five parameters. These parameters determine the function, shape and, in consequence, how each indicator value corresponds to the 0 to 1 satisfaction scale. For example, the Equation (1) to calculate the value function of indicator I1 in this research study has a decreasing concave shape (DCV). Therefore, initial and final value indicator variations will have greater satisfaction scale variations than middle-value indicator variations.

$$
V_{I^{1}}=A+B \cdot\left[1-e^{-K i\left(\frac{|X a l t-X m|}{C i}\right)^{P i}}\right]=B \cdot\left[1-e^{-0.01 \cdot\left(\frac{|X-2200|}{1100}\right)^{1.5}}\right]
$$

Equation (1) shows the previously mentioned parameters: $A=0$ is the response value to Xmax; $k i=0.01$ comes closer to the ordinate of the curve inflection point; Xalt $=X$ is each response to the indicator I1; Xm $=X \max =2200 € / \mathrm{m}^{2}$ is the maximum abscissa value considered for I1 in this indicator because it is decreasing, if it were increasing it would be Xm $=\mathrm{Xmin} ; \mathrm{Ci}=1100 € / \mathrm{m}^{2}$ comes closer to the abscissa value of the curve inflection point; 1.5 is the form factor for this concave curve. The parameter $B$ maintains the function within the 0 to 1 range as presented in Equation (2). This equation includes some of the aforementioned parameters and X $\min =50 € / \mathrm{m}^{2}$, which is the minimum abscissa value considered for I1.

$$
B=\left[1-e^{-K i\left(\frac{|X \max -X \min |}{C i}\right)^{P i}}\right]^{-1}=\left[1-e^{-0.01 \cdot\left(\frac{|2200-50|}{1100}\right)^{1.5}}\right]^{-1}
$$


Indicators I2 to I14 have other parameters that define their value functions shapes: two more DCV, one decreasing linear (DL), seven increasing convex (ICX), and three increasing linear (IL). The researchers have defined these parameters in the course of sessions. Table A8 in Appendix D presents the main parameters and information of each indicator value function with its related references. In these parameters the experts have considered it to be a priority to promote this new implementation and therefore to evaluate positively all small contributions to each alternative. In this sense, maximum and minimum values are respectively 100 and 0 for the assessed indicators using points. In indicators I 1 and I3, these values are $10 \%$ more or less of the maximum and minimum alternatives values.

The calculation of each indicator has also been designed in collaboration with experts. Table A9 in Appendix D summarizes the main considerations about these calculations.

In the last step of the sustainability assessment tool design, the $G S_{k}$ for each alternative is defined. As presented in Equation (3), $G S_{k}$ this is the addition of the partial satisfaction indexes of the three requirements $S I_{R i, k}$ considering each requirement weight from the previously presented requirement tree (Figure 1).

$$
G S_{k}=\sum_{i=1}^{j} \lambda_{R i, k} \cdot S I_{R i, k}
$$

Similarly, as shown in Figure 1, each of the three $S I_{R i, k}$ is obtained adding up their own criteria $C I_{R i, k}$ corrected considering their own weights. Finally, the $C I_{R i, k}$ is obtained adding up their own indicator's adimensional aforementioned $V_{I k}$, considering their own weights from Figure 1 . In this present study, this MIVES application also included a sensitive analysis in order to prove the robustness of this new tool.

\subsection{Focus Groups to Define a First Prototype and Workshop for a Specific School}

Based on the previous steps, one of the most sustainable alternatives was prototyped during a first participatory workshop with students to solve a specific school community problem, representative of this study sample. This alternative selection process, prototype and workshop were also done through Focus groups, which are valuable research tools capable of capturing information that will help to better manage the process of prototype development. This research tool has already been successfully combined with MIVES in previous research projects [39,40]. We also used Focus group as exploratory research in developing new surveys. There are four essential steps in conducting Focus groups: (1) planning (2) recruiting, (3) moderating, and (4) making an analysis and reporting [29]. In this sense, first, we created a purpose statement that reflected what we needed to know from the participant group. The research team drew up several questions on the planned workshops and the best ways to run them, the surveys and designing of the new prototype. When the purpose and desired outcomes had been defined and agreed upon, we identified who should participate in the three sessions, which included teaching team and research project members. One researcher was a moderator who led the group discussion, facilitated interaction among participants and maintained the high-quality interaction that will provide relevant information.

\section{Results}

\subsection{Defining the Problem and Case Study}

During this first step, the researchers defined the boundaries of this research project as follows: external solar control devices that are built using household waste during primary educational workshops and are employed for windows in existing Spanish schools. Primary education, also known as elementary, includes grades 1-6 for children from 6 to 12 years old in Spain [41]. These boundaries result from the sample main necessities: (a) external solar control devices; (b) reuse of household waste; and (c) children's awareness about the high generation of waste. Accordingly, the schools studied in this project are all Spanish primary schools. However, in order to be able to carry out a rigorous study with the time and resources available, the researchers defined an initial smaller representative sample. 
This simplified set public primary school is located in three representative municipalities within the greater metropolitan Barcelona area. Table 2 presents the main characteristics of these municipalities related to this research project $[42,43]$.

Table 2. Main characteristics for the municipalities where the sample schools are located.

\begin{tabular}{cccc}
\hline & Municipality $\mathbf{1}$ & Municipality 2 & Municipality 3 \\
\hline Name & Barcelona & Sant Boi de Llobregat & Torrelles de Llobregat \\
UTM coordinates ((WGS84) Zone 31T) & E: 429686.70 & E: 419270.66 & E: 414624.11 \\
Number of inhabitants (inh) & N: 4582259.10 & N: 4577599.01 & N: 4578716.42 \\
Density (inh/ $\left.\mathrm{km}^{2}\right)$ & 1608,746 & 82,402 & 5933 \\
Births & $15,873.2$ & 3838.0 & 437.5 \\
Deaths & 13,957 & 762 & 58 \\
Number of public primary schools & 16,003 & 658 & 35 \\
Number of schools given questionnaires & 169 & 14 & 2 \\
Solar irradiation (global horizontal & 30 & 14 & 2 \\
plane) (kWh/m ${ }^{2}$ da \& kWh/m $\left.{ }^{2}\right)$ & $(1.9-7.6)$ & 4.7 & 4.7 \\
Maximum temperature (June 2016) $\left({ }^{\circ} \mathrm{C}\right)$ & 32,5 & $(1.9-7.6)$ & $(1.9-7.6)$ \\
Gross domestic product $(\mathrm{GDP})$ per & 40.8 & 32 & 25 \\
capita (thousands of $€)$ & $82,597.1$ & 21.3 & 10.4 \\
Registered unemployment & & 5960.7 & 299.3 \\
\hline
\end{tabular}

To study this sample, a 10 questions questionnaire was designed in order to evaluate the satisfaction level by schools teaching teams regarding their solar control devices. This questionnaire is included in Appendix A. In the case of Barcelona, only three schools per district were given this questionnaire. Table 3 presents the results of these questionnaires that were considered in this research project to define the schools in the sample needs on solar control devices. As shown in this table, the most commonly used solar control device in the schools included in the sample at present are exterior roller shutters, which have been complemented with other solar control devices in order to improve school lighting and thermal comfort in almost all school centers.

Table 3. Results of questionnaires from schools which submitted answers related to solar control devices.

\begin{tabular}{ccccc}
\hline & & $\begin{array}{c}\text { Municipality } \\
\mathbf{1}\end{array}$ & $\begin{array}{c}\text { Municipalities } \\
\text { 2 and 3 }\end{array}$ & $\begin{array}{c}\text { Standard } \\
\text { Deviation }\end{array}$ \\
\hline Existing kind of solar control & $\begin{array}{c}\text { Exterior roller shutter } \\
\text { system (question 3) }\end{array}$ & $59 \%$ & $50 \%$ & 0.06 \\
& $\begin{array}{c}\text { Percentage of roller shutters } \\
\text { that have been complemented }\end{array}$ & $88 \%$ & $100 \%$ & 0.08 \\
\hline Lighting performance & High satisfaction & $34 \%$ & $62 \%$ & 0.20 \\
satisfaction for solar control & Average satisfaction & $24 \%$ & $19 \%$ & 0.04 \\
devices (question 4) & Low satisfaction & $42 \%$ & $19 \%$ & 0.16 \\
\hline Thermal performance & High satisfaction & $14 \%$ & $31 \%$ & 0.12 \\
satisfaction for solar control & Average satisfaction & $24 \%$ & $31 \%$ & 0.05 \\
devices (question 5) & Low satisfaction & $62 \%$ & $38 \%$ & 0.17 \\
\hline & work properly as new & $31 \%$ & $50 \%$ & 0.13 \\
Solar control devices & need minimum maintenance & $48 \%$ & $38 \%$ & 0.08 \\
(question 7) & need important repair & $7 \%$ & $6 \%$ & 0.00 \\
& need replacement & $14 \%$ & $6 \%$ & 0.05 \\
\hline
\end{tabular}

\subsection{Determining the Appropriate Alternatives}

This second step defined the most important parameters for this case study and assigned relevant values for each parameter following the aforementioned GMA. Table A3 presents the eight main parameters and their relevant values. 
These parameters do not generate specific solutions but types of solutions, which reduce the amount of generated alternatives and, therefore, simplify the whole process. For the first parameter about the position, two values include devices installed on the ground floor and other levels of the façade. Devices installed in the playground as isolated elements were outside the scope of this study and therefore discarded. The second parameter is mobility and includes two opposite values, either the device is fixed and immovable or moveable being foldable, retractable, or scrollable. The third parameter is the types of solar control devices and considers three relevant values according to the stated boundaries.

In consequence, interior devices are discarded. This study focuses on devices that students can control either manually or with up-down commands whereas fully automated devices are discarded. Venetian blinds, roller blinds, extensible awning, solar control glass, glass vinyl, transparent or opaque building integrated photovoltaic elements and building integrated solar thermal systems [20] have been discarded since they have been considered unable to be composed of household waste.

The fourth parameter is the type of household waste exposed to weathering [44], and four types are defined: (4.1) Bottles, either polyethylene terephthalate or high-density polyethylene previously used for food and drinking products; (4.2) Other containers, e.g., tetra briks, yogurt recipients, plastic cups ...; ; (4.3) opaque or translucent superficial elements, such as opened tetra briks, polystyrene and polyethylene plates, dishes, egg containers covers ... ; and (4.4) Small elements such as bottle covers. On the other hand, the following materials have been discarded: (a) waste containers whose shape and material properties could cause injuries, such as metals, glass, home appliances ... ; (b) waste that may have been in contact with toxic products and allergens such as cleaning products and paints; and (c) low durability products such as plastic bags, paper and paperboard that cannot last exposed to exterior weathering during one school term. The fifth parameter is the filling material and has two operational values: waste such as expanded polystyrene, paper, paperboard, plastic bags and soil to grow plants. Water as filling material has also been discarded to avoid problems related to stagnant water such as algae, mosquitoes ... [45].

The last three parameters are elements which are not waste but produced and bought for the device manufacture and application. The sixth parameter is the type of auxiliary material and has five relevant values. The seventh parameter is the type of renewable energy system and has two possible values: (7.1) rigid small photovoltaic (PV) panels and (7.2) Piezoelectric elements. This project discards the following systems: (a) biomass, hydro, geothermal and marine technologies because they are not suitable for the case study [46]; (b) solar thermal because of their inadequate pipe temperatures and pressures for children; (c) adsorption systems because they are too complex; and d) non-rigid flexible or amorphous PV elements [47], because waste alternatives are made of limited pieces and lack amorphous surfaces. The last parameter is the type of device that consumes the energy generated by the renewable system and has two values: (8.1) a fan that optimizes ventilation and (8.2) light-emitting diodes (LED). The following have been discarded: (a) connection to the electric network or batteries because of the low amount of energy generated and (b) connection to a system to pump water upwards and then generate energy via hydropower because of its complexity and inconveniences of water running circuits prone to sanitary and durability issues [45].

In the course of these sessions, experts have used GMA and CCA to reduce the amount of possible solar control alternatives which were developed by these parameters and their possible values to a subset that has primary internal consistency. The internal relationships among these eight parameters have been studied by an analysis-synthesis process. These parameters were compared with one another by means of a cross-impact matrix which took into account the boundaries of the project and the consequent inconsistencies, which are classified and presented in Table A4 in Appendix C. As shown there were logical and empirical constraints but no normative constraints.

From this GMA resulted in the 82 feasible alternatives incorporated in Tables A1 and A2 in Appendix B, one table for each value of parameter 1 . At this point, the researchers studied cross-impact matrixes without particular configurations or subsets (Table A5) in order to find 14 more alternatives 
that were non-logical and unexpected, which are presented in Tables A6 and A7 in Appendix C. To do so, several values were added although they were incompatible with the stated boundaries. These added values for parameter 3 are "3.4. Solid panels", "3.5. Solar control glass" and "3.6. Roller shutters" and for parameter 4 are " 4.5 cardboard" and " 4.6 plastic bags". Consequently, from these final total 96 alternatives, the 14 non-logical options helped the researchers to contrast and confirm the 82 logical alternatives, as explained in the discussion section.

\subsection{Results for Sustainability Assessments of Alternatives}

This part determines the sustainability of the aforementioned 96 alternatives as well as the sustainability of exterior roller shutters, which are the most commonly used solar control device of the sample as previously shown in Table 3. These roller shutters are devices beyond these new sustainability assessment tool boundaries. Nevertheless, they have been assessed to have more quantitative information when comparing them to the experimental prototypes.

The main results of this sustainability assessment are the global sustainability index for each alternative $G S_{k}$ and the three partial satisfaction indexes of the economic, environmental, and social requirements $S I_{R 1, k}, S I_{R 2, k}$, and $S I_{R 3, k}$, respectively.

Table A10 in Appendix D presents all these indexes for all the 97 assessed devices. Table 4 illustrates the ten alternatives that have maximum partial satisfaction indexes and maximum global sustainability indexes.

Table 4. Sensitivity analysis comparing two other weight scenarios of the solar control device alternative types.

\begin{tabular}{|c|c|c|c|c|c|}
\hline $\begin{array}{l}\text { Sustainability } \\
\text { Requirement }\end{array}$ & $\begin{array}{c}\text { Research } \\
\text { Project } \\
\text { Scenario (E1) }\end{array}$ & $\begin{array}{c}\text { Neutral } \\
\text { Scenario (E2) }\end{array}$ & $\begin{array}{l}\text { Economically } \\
\text { Biased } \\
\text { Scenario (E3) }\end{array}$ & $\begin{array}{l}\text { Variation from } \\
\text { Scenario E1 to } \\
\text { E2 }\end{array}$ & $\begin{array}{c}\text { Variation from } \\
\text { Scenario E1 to } \\
\text { E3 }\end{array}$ \\
\hline Economic & $10 \%$ & $33.33 \%$ & $50 \%$ & & \\
\hline Environmental & $20 \%$ & $33.33 \%$ & $30 \%$ & & \\
\hline \multirow[t]{2}{*}{ Social } & $70 \%$ & $33.33 \%$ & $20 \%$ & & \\
\hline & $\mathrm{GS}_{\mathrm{k}}$ & $\mathrm{GS}_{\mathrm{k}}$ & $\mathrm{GS}_{\mathrm{k}}$ & & \\
\hline Alternative 1 & 0.81 & 0.81 & 0.82 & $0 \%$ & $-1 \%$ \\
\hline Alternative 24 & 0.82 & 0.78 & 0.78 & $4 \%$ & $4 \%$ \\
\hline Alternative 25 & 0.82 & 0.78 & 0.78 & $4 \%$ & $4 \%$ \\
\hline Alternative 26 & 0.82 & 0.81 & 0.80 & $1 \%$ & $2 \%$ \\
\hline Alternative 28 & 0.82 & 0.79 & 0.75 & $3 \%$ & $7 \%$ \\
\hline Alternative 42 & 0.81 & 0.80 & 0.81 & $1 \%$ & $0 \%$ \\
\hline Alternative 65 & 0.82 & 0.77 & 0.76 & $5 \%$ & $6 \%$ \\
\hline Alternative 66 & 0.82 & 0.77 & 0.77 & $5 \%$ & $5 \%$ \\
\hline Alternative 67 & 0.80 & 0.78 & 0.75 & $2 \%$ & $5 \%$ \\
\hline \multirow[t]{2}{*}{ Alternative 69} & 0.80 & 0.73 & 0.67 & $7 \%$ & $13 \%$ \\
\hline & & & Average & $3 \%$ & $5 \%$ \\
\hline
\end{tabular}

In general, the results showed that the most sustainable alternatives with maximum global index are movable exterior curtains and louvres built using bottles and other plastic or tetra briks waste, respectively, and integrated with PV panels which are connected to fans.

\subsection{First Prototype of One of the Most Sustainable Alternative for a Specific Case Study}

The first prototype was defined taking into account their future installation in a specific school included in the sample. This educational center was chosen from the 46 interviewed centers of the 185 sample schools, presented in Table 2. This center was chosen because it had both the gravest lack of solar controls and a teaching team more prone to collaborate in this project, which had been proven to be crucial for participative projects in schools [48]. The main characteristics of this school [49] are representative of an important part of schools included in this sample study. This first design and 
prototype was $0.6 \times 1.95 \mathrm{~m}$ and solved part of one window solar control, although it aims to solve the solar control issues on the 33 classrooms windows on the same building façade in the future. These windows have these traits in common: south-east orientation, $1.95 \mathrm{~m}$ high, $2.40 \mathrm{~m}$ wide, have no shading from nearby buildings, have curtains as control devices. Following these characteristics, the aforementioned Focus groups chose alternative 24, which is ground floor louvres, that are movable, use superficial waste, incorporate PV and a fan. The main reasons for choosing this alternative is that it had the best social criteria sustainability index and, therefore, was more flexible to incorporate children's design \& creativity. Children could carry out a higher percentage of its installation and had better real-time feedback to students for its performance. Among the different possibilities within this alternative, vertical louvres were chosen according both to the orientation and this school's teaching team preferences. Finally, tetra briks were chosen because this school had an extra amount of tetra briks available as part of a European Union program that was providing milk to the school [49].

\section{Discussion}

This section discusses the previous results about this project sample, the 96 new solar control devices alternatives plus the current roller shutters and the first design and prototype for the most sustainable device.

In Section 3, the analysis of the sample proves teaching teams' dissatisfaction regarding their schools solar control devices. The sample schools are representative of a much broader sample consisting of numerous Spanish educational centers with similar circumstances. Consequently, the researchers expect that a huge number of primary education teams in Spain have low satisfaction levels for their current solar control devices, regarding thermal and lighting performance and their workability.

Up to 96 alternatives have been defined using GMA and CCA, which are listed in Appendix B. Up to 82 alternatives represent the main types of solar control devices composed of household waste, incorporating energy systems, and able to be assembled during participatory workshops in primary schools. This representability has been ensured by relying on the qualified design process applying the comprehensive methodologies incorporating sessions with multidisciplinary experts. The rest are 14 non-logical alternatives beyond some of these research limits have also been generated to prove it. All alternatives are types of solar control devices and, therefore, each one includes numerous possible specific solutions that will be studied in the future steps of this research project. This simplification gives flexibility to the results, as has already been explained in the methodology.

The 96 alternatives and the roller shutters sustainability assessment results are shown in Appendix D. The ten most sustainable alternatives, their three requirements satisfaction $\left(S I_{R i, k}\right)$ and their Global Index $\left(G S_{k}\right)$ are presented in Table 3. These best alternative types are exterior louvres and curtains. They differ because exterior louvres have the best social indexes while exterior curtains have the best environmental indexes. These most environmentally friendly alternatives incorporate waste fill or soil to grow plants inside containers. Regarding social requirements, which are the most important for this research project, the best solutions incorporate PV and fans. On the other hand, the 14 non-logical alternatives had the lowest global sustainability indexes and the lowest environmental and social indexes, which are the most crucial indicators for this project as previously explained. This confirms that GMA has properly defined the appropriate alternatives for this project. On the other hand, roller shutters are out of the scope for this research project and, therefore, their low sustainability index was expected, mainly because it is not possible to use them for workshops, since they give no feedback to students, do not allow children's design and their hydrothermal and light control behavior should improve for educational purposes as presented in Section 3.1. To prove the robustness of these results, a sensitivity analysis has been carried out considering two other scenarios with different requirements weights as shown in Table 3. The two other considered scenarios are if decision makers' had either a neutral or an economically biased point of view. The neutral scenario gives the same third part weight to each requirement. The Economic scenario gives $50 \%$ of 
the weight to the economic requirement, $30 \%$ to the environmental and $20 \%$ to the social. As seen in Table 3, the variation for most alternatives is very low, with the maximum variation occurring in alternatives 11 and 84, because they are the worst from the environmental and social points of view.

Defining and carrying out the first prototype and workshop as shown in Figure 2 [49] has been useful to: (a) confirm it is possible to build real mobile louvres mainly based on household waste material as Table 4 and Figure 3 present; (b) confirm children can build them; (c) confirm children can be more aware of global waste problem and of solar control devices from this workshop; and (d) detect the strengths and weaknesses encountered in this first workshop in order to improve future versions in terms of contents, times, phases, materials, etc.
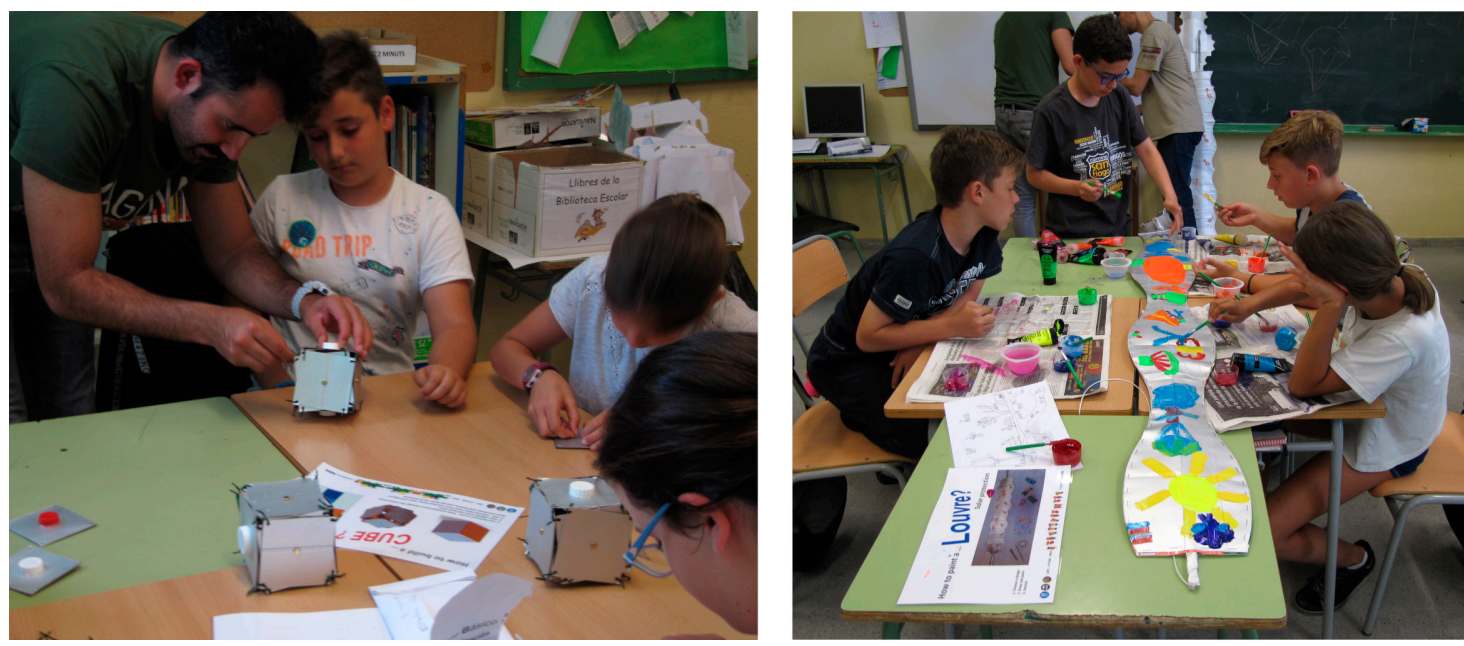

Figure 2. Children developing waste-based solar control devices during the first workshop.
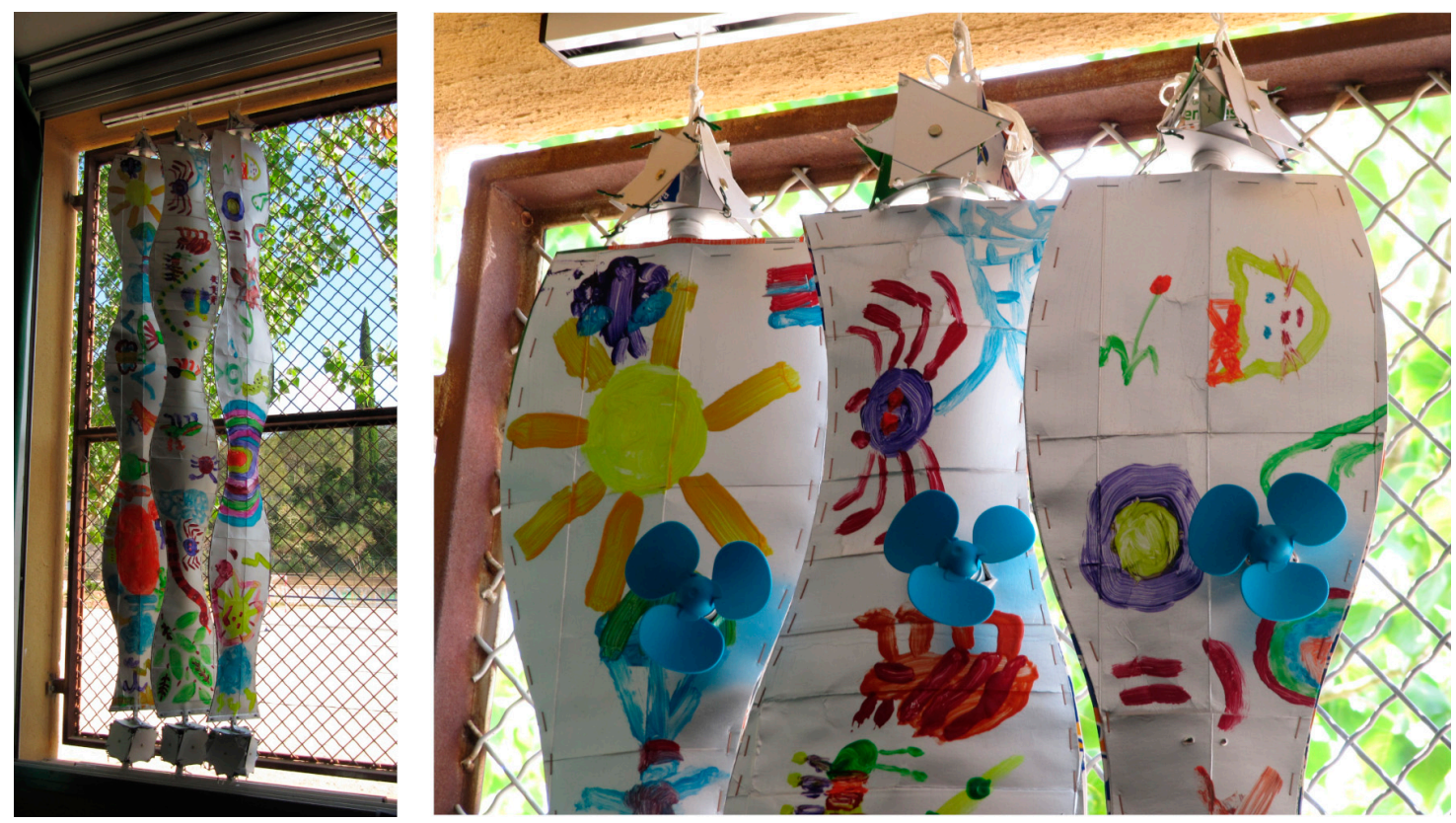

Figure 3. First waste-based solar control devices prototype developed during the first workshop.

\section{Conclusions}

Compared to the previous similar projects presented in the introduction, this research project main novelties are: (a) the definition of a new methodology that combines GMA, MIVES, and Focus groups for the first time and (b) the application of this methodology in order to find the most sustainable 
alternative among all feasible possible waste based solar control devices for primary workshops about sustainable architecture.

In consequence, this project has satisfied its objectives because it has: found all the appropriate waste based solar control devices alternatives to be built in primary workshops; assessed the sustainability of these alternatives to determine the most sustainable devices; and has built the first new solar control devices prototypes during a first workshop. It has also contributed to environmental awareness, particularly in the 46 schools interviewed and the schools where the first prototype and workshop has been developed.

The proposed solutions are composed of household waste compatible with primary children's safety, incorporate energy systems and solve the sample schools' serious lack of solar control. Therefore, they contribute to provide maximum comfort level and energy efficiency in these schools. Furthermore, being mainly composed of waste, they have almost zero-cost and zero-emission factors.

These project methodologies have once more proven very useful to carry out research because of: (a) GMA efficiency to identify the appropriate alternatives; (b) MIVES versatility to generate agile MCDM tools for specific problems; and (c) Focus group capacity to consider all crucial particularities. In this research project, it was essential to be able to consider all appropriate alternatives using GMA and it was difficult to define them all because of the novelty of using household waste as a material for workshops to build solar control devices. The MIVES sustainability assessment was also crucial in order to find the best alternative in terms of cost, thermal, light and color performance among others indicators that have been studied in depth.

In this sense, the next steps in this research project will assess in depth these aspects of this device: its thermal and lighting performance, its components mechanical and durability performance and its overall sustainability benefits. In the future, this project will also define a definitive version of its workshop based on the latest advances in primary education pedagogy.

As recommendations for future studies, this project considers these methodologies applicable to similar challenges after adapting them to each case and encourages researchers to do so by relying on this present study. For example, they can be used to define and assess waste based solar protections for playgrounds or high schools. In this sense, both this and other similar projects are expected to promote awareness and better management of our Society critical waste generation.

Author Contributions: O.P. designed this research project and wrote the manuscript helped by S.H. while O.P., S.H. and D.P. contributed equally to carry out this research steps and analyze their results.

Funding: This work was supported by a 2017 Leonardo Grant for Researchers and Cultural Creators, BBVA Foundation.

Acknowledgments: The authors are grateful for the collaboration by all the experts from the Educational Department, the Barcelona Energy Agency, Barcelona schools Consorci, Barcelona Town Hall Escoles sostenibles and Fàbrica del sol departments.

Conflicts of Interest: The authors declare no conflicts of interest.

\section{Appendix A}

First questionnaire

(1) What's the name of your school center?

(2) In which municipality is located your school?

(3) What kind of solar control device does your school building have?
a. Exterior roller shutter
b. Not movable Louvre blinds
c. Exterior shutters
d. Exterior textile blinds
e. Exterior non-movable awning 
f. Exterior roller awning

g. Balconies and cantilevers

h. Pergola Shelter in the playground close to openings

i. Awnings in the playground close to openings

j. Vegetation and trees

k. Textile interior curtains

1. Dark window glazing

m. Special window glazing with drawings

n. Louvre blinds with Photovoltaic panels incorporated

o. Other

p. None

(4) Do you consider that these devices are flexible enough considering the entrance of sunlight in order to do the different learning activities you do?
a. Yes, always
b. Yes, in $75 \%$ of the cases
c. Yes, in $50 \%$ of the cases
d. Yes, in $25 \%$ of the cases
e. No, never.

(5) Do you consider that these devices are able to sufficiently control the entrance of sunlight in order to achieve thermal comfort of school interior spaces?
a. Yes, always
b. Yes, in $75 \%$ of the cases
c. Yes, in $50 \%$ of the cases
d. Yes, in $25 \%$ of the cases
e. No, never.

(6) How long ago were these devices assembled?
a. $0-2$ years
b. $3-5$ years
c. $6-10$ years
d. 11-25 years
e. More than 25 years

(7) Are these devices working properly?
a. Yes, they are new
b. They need minimum maintenance work, such as paining, varnishing ...
c. They need an important rehabilitation as they are broken in several parts.
d. They should be replaced for new devices since they don't work and/or are all broken.

(8) Which of the schools you know have the best solar protection to control light and temperature for spaces in those centers?

(9) Which of the schools you know have the worst solar protection to control light and temperature for spaces in those centers?

(10) Would you be willing to do a workshop with children and teachers to build solar protections with household waste during the next year and a half?
a. Yes 
b. I would like to know more about this research project before deciding

c. No

\section{Appendix B}

Table A1. Alternative solar protection devices for ground floor installation (1.1).

\begin{tabular}{|c|c|c|c|c|c|c|c|}
\hline Mobility & Control & Waste & Filling & Connectors & System & Use & $\mathbf{N}^{\circ}$ \\
\hline \multirow{23}{*}{ 2.1. Fixed } & \multirow{3}{*}{ 3.1. Louvre blinds } & \multirow{3}{*}{ 4.3. Superficial } & \multirow{3}{*}{ N/A } & \multirow{3}{*}{$6.1+6.2+6.3$} & \multirow{2}{*}{ 7.1. PV } & 8.1. Fan & 1 \\
\hline & & & & & & 8.2. LED & 2 \\
\hline & & & & & 7.2. Wind & 8.2. LED & 3 \\
\hline & \multirow{12}{*}{ 3.2. Exterior curtains } & \multirow{3}{*}{ 4.1. Plastic Bottles } & \multirow{3}{*}{$\begin{array}{l}\text { 5.1. Waste } \\
+5.2 \text {. Soil }\end{array}$} & \multirow{3}{*}{$6.1+6.2+6.3$} & \multirow{2}{*}{ 7.1. PV } & 8.1. Fan & 4 \\
\hline & & & & & & 8.2. LED & 5 \\
\hline & & & & & 7.2. Wind & 8.2. LED & 6 \\
\hline & & \multirow{3}{*}{$\begin{array}{l}\text { 4.2. Other } \\
\text { containers }\end{array}$} & \multirow{3}{*}{$\begin{array}{l}\text { 5.1. Waste } \\
+5.2 \text {. Soil }\end{array}$} & \multirow{3}{*}{$6.1+6.2+6.3$} & \multirow{2}{*}{ 7.1. PV } & 8.1. Fan & 7 \\
\hline & & & & & & 8.2. LED & 8 \\
\hline & & & & & 7.2. Wind & 8.2. LED & 9 \\
\hline & & \multirow{3}{*}{ 4.3. Superficial } & \multirow{3}{*}{ N/A } & \multirow{3}{*}{$6.1+6.2+6.3$} & \multirow{2}{*}{ 7.1. PV } & 8.1. Fan & 10 \\
\hline & & & & & & 8.2. LED & 11 \\
\hline & & & & & 7.2. Wind & 8.2. LED & 12 \\
\hline & & \multirow{3}{*}{ 4.4. Small } & \multirow{3}{*}{ 5.2. Soil } & \multirow{3}{*}{$6.1+6.3$} & \multirow{2}{*}{ 7.1. PV } & 8.1. Fan & 13 \\
\hline & & & & & & 8.2. LED & 14 \\
\hline & & & & & 7.2. Wind & 8.2. LED & 15 \\
\hline & \multirow{8}{*}{$\begin{array}{l}\text { 3.3. Sun sail \& } \\
\text { awnings }\end{array}$} & & & & 71 PV & 8.1. Fan & 16 \\
\hline & & 4.1. Plastic Bottles & 5.1. Waste & $6.1+6.2$ & 1.1. $\mathrm{PV}$ & 8.2. LED & 17 \\
\hline & & 4.2. Other & & & 71 PV & 8.1. Fan & 18 \\
\hline & & containers & 5.1. Waste & $6.1+6.2$ & $1.1 .1 \mathrm{v}$ & 8.2. LED & 19 \\
\hline & & 4 Sunorficial & $U_{0}$ & & $71 \mathrm{PV}$ & 8.1. Fan & 20 \\
\hline & & 4.3. Superticial & $\mathrm{N} / \mathrm{A}$ & $6.1+6.2+6.3$ & & 8.2. LED & 21 \\
\hline & & & & & $71 . P V$ & 8.1. Fan & 22 \\
\hline & & 4.4. Small & N/A & $6.1+6.3$ & $1.1 .1 \mathrm{v}$ & 8.2. LED & 23 \\
\hline & & & & $6.1+6.2+6.3+$ & 7.1. PV & 8.1. Fan & 24 \\
\hline & 3.1. Louvres & 4.3. Superficial & N/A & 6.5 & & 8.2. LED & 25 \\
\hline & & & & & $71 \mathrm{PV}$ & 8.1. Fan & 26 \\
\hline & & 4.1. Plastic Bottles & 5.1. Waste & $6.1+6.2+6.5$ & $1.1 .1 \mathrm{v}$ & 8.2. LED & 27 \\
\hline & & 4.2. Other & & & 7.1. PV & 8.1. Fan & 28 \\
\hline & 32 Eytorior & containers & 5.1. Waste & $6.1+6.2+6.5$ & & 8.2. LED & 29 \\
\hline & 3.2. Exterior curtams & s 8 s. is & & $6.1+6.2+6.3+$ & $71 \mathrm{PV}$ & 8.1. Fan & 30 \\
\hline & & 4.3. Superticial & $\mathrm{N} / \mathrm{A}$ & 6.5 & & 8.2. LED & 31 \\
\hline Movable & & & & $6.1+6.2+6.3+$ & 7.1. PV & 8.1. Fan & 32 \\
\hline & & 4.4. Small & N/A & 6.5 & & 8.2. LED & 33 \\
\hline & & & & & $71 \mathrm{PV}$ & 8.1. Fan & 34 \\
\hline & & 4.1. Plastic Bottles & 5.1. Waste & $6.1+6.2+6.5$ & & 8.2. LED & 35 \\
\hline & & 4.2. Other & & & 7.1. PV & 8.1. Fan & 36 \\
\hline & 230 & containers & 5.1. Waste & $6.1+6.2+6.5$ & & 8.2. LED & 37 \\
\hline & & & & $6.1+6.2+6.3+$ & 7.1. PV & 8.1. Fan & 38 \\
\hline & & 4.3. Superficial & N/A & 6.5 & & 8.2. LED & 39 \\
\hline & & & & $6.1+6.2+6.3+$ & $71 \mathrm{PV}$ & 8.1. Fan & 40 \\
\hline & & 4.4. Small & $\mathrm{N} / \mathrm{A}$ & 6.5 & & 8.2. LED & 41 \\
\hline
\end{tabular}


Table A2. Alternative solar protection devices for installation in levels from first floor on (1.2).

\begin{tabular}{|c|c|c|c|c|c|c|c|}
\hline Mobility & Control & Waste & Filling & Connectors & System & Use & $\mathbf{N}^{\circ}$ \\
\hline \multirow{23}{*}{ 2.1. Fixed } & \multirow{3}{*}{ 3.1. Louvre blinds } & \multirow{3}{*}{ 4.3. Superficial } & \multirow{3}{*}{$\mathrm{N} / \mathrm{A}$} & \multirow{3}{*}{$6.1+6.2+6.3$} & \multirow[b]{2}{*}{ 7.1. PV } & 8.1. Fan & 42 \\
\hline & & & & & & 8.2. LED & 43 \\
\hline & & & & & 7.2. Wind & 8.2. LED & 44 \\
\hline & \multirow{12}{*}{ 3.2. Exterior curtains } & \multirow{3}{*}{ 4.1. Plastic Bottles } & \multirow{3}{*}{ 5.1. Waste } & \multirow{3}{*}{$6.1+6.2$} & \multirow{2}{*}{ 7.1. PV } & 8.1. Fan & 45 \\
\hline & & & & & & 8.2. LED & 46 \\
\hline & & & & & 7.2. Wind & 8.2. LED & 47 \\
\hline & & \multirow{3}{*}{ 4.2. Other containers } & \multirow{3}{*}{ 5.1. Waste } & \multirow{3}{*}{$6.1+6.2$} & \multirow{2}{*}{ 7.1. PV } & 8.1. Fan & 48 \\
\hline & & & & & & 8.2. LED & 49 \\
\hline & & & & & 7.2. Wind & 8.2. LED & 50 \\
\hline & & \multirow{3}{*}{ 4.3. Superficial } & \multirow{3}{*}{$\mathrm{N} / \mathrm{A}$} & \multirow{3}{*}{$6.1+6.2+6.3$} & \multirow[b]{2}{*}{ 7.1. PV } & 8.1. Fan & 51 \\
\hline & & & & & & 8.2. LED & 52 \\
\hline & & & & & 7.2. Wind & 8.2. LED & 53 \\
\hline & & \multirow{3}{*}{ 4.4. Small } & \multirow{3}{*}{$\mathrm{N} / \mathrm{A}$} & \multirow{3}{*}{$6.1+6.3$} & \multirow{2}{*}{ 7.1. PV } & 8.1. Fan & 54 \\
\hline & & & & & & 8.2. LED & 55 \\
\hline & & & & & 7.2. Wind & 8.2. LED & 56 \\
\hline & \multirow{8}{*}{$\begin{array}{l}\text { 3.3. Sun sail \& } \\
\text { awnings }\end{array}$} & & & & & 8.1. Fan & 57 \\
\hline & & 4.1. Plastic Bottles & 5.1. Waste & $6.1+6.2$ & 7.1. PV & 8.2. LED & 58 \\
\hline & & & & & & 8.1. Fan & 59 \\
\hline & & 4.2. Other containers & 5.1. Waste & $6.1+6.2$ & 7.1. PV & 8.2. LED & 60 \\
\hline & & 42 Sunorficiol & & & & 8.1. Fan & 61 \\
\hline & & 4.3. Supertıcial & N/A & $6.1+6.2+6.3$ & 7.1. PV & 8.2. LED & 62 \\
\hline & & & & & & 8.1. Fan & 63 \\
\hline & & 4.4. Small & N/A & $6.1+6.3$ & 7.1. PV & 8.2. LED & 64 \\
\hline & & & & $6.1+6.2+6.3$ & & 8.1. Fan & 65 \\
\hline & 3.1. Louvres & 4.3. Supertıcial & N/A & +6.5 & 7.1. PV & 8.2. LED & 66 \\
\hline & & & & & & 8.1. Fan & 67 \\
\hline & & 4.1. Plastic Bottles & 5.1. Waste & $6.1+6.2+6.5$ & 7.1. PV & 8.2. LED & 68 \\
\hline & & & & & & 8.1. Fan & 69 \\
\hline & 3) Fyterior curtaing & 4.2. Other containers & 5.1. Waste & $6.1+6.2+6.5$ & 7.1. PV & 8.2. LED & 70 \\
\hline & 3.2. Exterior curtants & 43 Sunerficial & $N / A$ & $6.1+6.2+6.3$ & 1 & 8.1. Fan & 71 \\
\hline & & 4.3. Supernicial & $\mathrm{N} / \mathrm{A}$ & +6.5 & 7.1. PV & 8.2. LED & 72 \\
\hline 2.2. Movable & & & & $6.1+6.2+6.3$ & & 8.1. Fan & 73 \\
\hline & & 4.4. Small & N/A & +6.5 & 7.1. PV & 8.2. LED & 74 \\
\hline & & & & & & 8.1. Fan & 75 \\
\hline & & 4.1. Plastic Bottles & 5.1. Waste & $6.1+6.2+6.5$ & 7.1. PV & 8.2. LED & 76 \\
\hline & & & & & & 8.1. Fan & 77 \\
\hline & & 4.2. Other containers & 5.1. Waste & $6.1+6.2+6.5$ & 7.1. PV & 8.2. LED & 78 \\
\hline & 3.3. Sun sall & $42 C_{1}$ & & $6.1+6.2+6.3$ & & 8.1. Fan & 79 \\
\hline & & 4.3. Superticial & $\mathrm{N} / \mathrm{A}$ & +6.5 & 7.1. PV & 8.2. LED & 80 \\
\hline & & & & $6.1+6.2+6.3$ & & 8.1. Fan & 81 \\
\hline & & 4.4. Small & $\mathrm{N} / \mathrm{A}$ & +6.5 & 7.1. PV & 8.2. LED & 82 \\
\hline
\end{tabular}




\section{Appendix C}

Table A3. Main parameters for this study case and their relevant values.

\begin{tabular}{ll}
\hline Parameter & Relevant Values \\
\hline 1. Position of the solar control device in the façade & $\begin{array}{l}\text { 1.1. Ground floor } \\
\text { 1.2. First floor }\end{array}$ \\
\hline 2. Mobility of the solar control device & $\begin{array}{l}\text { 2.1. Fixed } \\
\text { 2.2. Movable }\end{array}$ \\
\hline \multirow{2}{*}{ 3. Types of solar control devices } & 3.1. Louvre blinds \\
& 3.2. Exterior curtains \\
& 3.3. Sun sails \& awnings \\
4. Type of domestic reused waste exposed to weathering & 4.1. Plastic Bottles \\
& $\begin{array}{l}\text { 4.2. Other containers } \\
\text { 4.3. Superficial elements }\end{array}$ \\
\hline 5. Type of materials filling containers and bottles & 5.1. Filling waste \\
& 5.2. Soil with plants \\
\hline & 6.1. Plastic or metallic connections \\
6. Types of auxiliary materials & 6.2. Plastic or metallic profiles \\
& 6.3. Nylon or cloth twines \\
7. Types of renewable energy systems & 6.4. Adhesive \\
\hline \multirow{2}{*}{ 8. Types of devices that use the energy produced } & 6.5. Mobile system \\
\hline
\end{tabular}

Table A4. Inconsistencies considered in the GMA and CCA.

\begin{tabular}{ll}
\hline Type of Inconsistency & Relevant Values \\
\hline \multirow{3}{*}{ 1. Logical contradictions } & $\begin{array}{l}\text { Value } 3.1 \text { only made with } 4.3 \text { because louvre elements are superficial. } \\
\text { Values } 5.1 \text { and } 5.2 \text { only for values } 4.1 \text { and } 4.2 \text { because filling needs a recipient to } \\
\text { be filled. } \\
\text { Value } 6.5 \text { only logical with value } 2.2 .\end{array}$ \\
\hline & $\begin{array}{l}\text { Value } 5.2 \text { only for } 1.1 \text { because in the ground floor the problems from leaking } \\
\text { plants will be less. Value } 8.1 \text { only with } 7.1 \text { because } 7.2 \text { will involve ventilation for } \\
\text { 2. Empirical constraints }\end{array}$ \\
& $\begin{array}{l}\text { Value } 2.2 \text { incompatible with } 5.1 \text { and } 7.2 \text { because resulting alternatives high } \\
\text { complexity. }\end{array}$ \\
& Value 3.3 incompatible with 7.2 because the horizontal position limits its viability. \\
\hline 3. Normative constraints & None \\
\hline
\end{tabular}

To obtain unexpected alternatives, matrixes without particular configurations were prepared such as: 
Table A5. Unexpected solar control devices alternatives types.

\begin{tabular}{|c|c|c|c|}
\hline & 4.3. Superficial & 4.5. Cardboard & 4.6. Plastic Bags \\
\hline \multicolumn{4}{|l|}{ 3.1. Louvre blinds } \\
\hline \multicolumn{4}{|l|}{ 3.2. Exterior curtains } \\
\hline \multicolumn{4}{|l|}{ 3.3. Sun sails \& awnings } \\
\hline 3.4. Solid panels & UA & & \multirow{3}{*}{ UA } \\
\hline 3.5. Solar control glass & & & \\
\hline 3.6. Roller shutters & UA & UA & \\
\hline
\end{tabular}

Legend: UA-Unexpected Alternative.

From this matrix the following alternatives have been added:

Table A6. Added alternatives 83 to 89 for ground floor solar protective devices (1.1).

\begin{tabular}{|c|c|c|c|c|c|c|c|}
\hline Mobility & Control & Waste & Filling & Connectors & System & Use & $\mathbf{N}^{\circ}$ \\
\hline \multirow{4}{*}{ 2.1. Fixed } & \multirow{2}{*}{ 3.4. Solid panels } & \multirow[b]{2}{*}{ 4.5. Cardboard } & \multirow{2}{*}{$\mathrm{N} / \mathrm{A}$} & \multirow{2}{*}{$6.1+6.2+6.3$} & \multirow{2}{*}{ 7.1. PV } & 8.1. Fan & 83 \\
\hline & & & & & & 8.2. LED & 84 \\
\hline & \multirow{2}{*}{$\begin{array}{l}\text { 3.5. Solar control } \\
\text { glass }\end{array}$} & 4.3. Superficial & $\mathrm{N} / \mathrm{A}$ & 6.4 & $\mathrm{~N} / \mathrm{A}$ & N/A & 85 \\
\hline & & 4.6. Plastic bags & $\mathrm{N} / \mathrm{A}$ & 6.4 & $\mathrm{~N} / \mathrm{A}$ & $\mathrm{N} / \mathrm{A}$ & 86 \\
\hline \multirow{3}{*}{ 2.2. Movable } & 3.6. Roller shutters & 4.3. Superficial & $\mathrm{N} / \mathrm{A}$ & $6.1+6.2+6.3+6.5$ & 7.1. PV & 8.2. LED & 87 \\
\hline & \multirow{2}{*}{ 3.4. Solid panels } & \multirow[b]{2}{*}{ 4.5. Cardboard } & \multirow[b]{2}{*}{$\mathrm{N} / \mathrm{A}$} & \multirow[b]{2}{*}{$6.1+6.2+6.3+6.5$} & \multirow[b]{2}{*}{ 7.1. PV } & 8.2. Fan & 88 \\
\hline & & & & & & 8.2. LED & 89 \\
\hline
\end{tabular}

Table A7. Added alternatives 90 to 96 for solar protective devices in levels from first floor on (1.2).

\begin{tabular}{|c|c|c|c|c|c|c|c|}
\hline Mobility & Control & Waste & Filling & Connectors & System & Use & $\mathbf{N}^{\circ}$ \\
\hline \multirow{4}{*}{ 2.1. Fixed } & \multirow[b]{2}{*}{ 3.4. Solid panels } & \multirow[b]{2}{*}{ 4.5. Cardboard } & \multirow[b]{2}{*}{ N/A } & \multirow[b]{2}{*}{$6.1+6.2+6.3$} & \multirow[b]{2}{*}{ 7.1. PV } & 8.1. Fan & 90 \\
\hline & & & & & & 8.2. LED & 91 \\
\hline & \multirow{2}{*}{$\begin{array}{l}\text { 3.5. Solar control } \\
\text { glass }\end{array}$} & 4.3. Superficial & $\mathrm{N} / \mathrm{A}$ & 6.4 & N/A & N/A & 92 \\
\hline & & 4.6. Plastic bags & N/A & 6.4 & N/A & N/A & 93 \\
\hline \multirow{3}{*}{ 2.2. Movable } & 3.6. Roller shutters & 4.3. Superficial & $\mathrm{N} / \mathrm{A}$ & $6.1+6.2+6.3+6.5$ & 7.1. PV & 8.2. LED & 94 \\
\hline & \multirow[b]{2}{*}{ 3.4. Solid panels } & \multirow{2}{*}{ 4.5. Cardboard } & \multirow[b]{2}{*}{ N/A } & \multirow[b]{2}{*}{$6.1+6.2+6.3+6.5$} & \multirow[b]{2}{*}{ 7.1. PV } & 8.2. Fan & 95 \\
\hline & & & & & & 8.2. LED & 96 \\
\hline
\end{tabular}

\section{Appendix D}

Table A8. Main parameters and information for each indicator (Ix) value function.

\begin{tabular}{|c|c|c|c|c|c|c|c|c|}
\hline $\mathbf{I}_{\mathbf{x}}$ & Unit & $X_{\max }$ & $X_{\min }$ & $\mathrm{Ci}$ & $\mathbf{K i}$ & $\mathbf{P i}$ & Shape & References \\
\hline I1 & $\left(€ / \mathrm{m}^{2}\right)$ & 2200 & 50 & 1100 & 0.01 & 1.5 & $\mathrm{DCV}$ & {$[50,51]$} \\
\hline $\mathrm{I} 2$ & (points) & 100 & 0 & 50 & 0.01 & 1.5 & $\mathrm{DCV}$ & [11] \\
\hline I3 & $\left(\mathrm{kgCO}_{2} / \mathrm{m}^{2}\right)$ & 600 & 10 & 300 & 0.01 & 1 & DL & [51] \\
\hline $\mathrm{I} 4$ & (points) & 100 & 0 & 50 & 0.01 & 0.5 & $\mathrm{ICX}$ & {$[6,52]$} \\
\hline I5 & (points) & 100 & 0 & 50 & 0.01 & 1 & IL & [53] \\
\hline I6 & (points) & 100 & 0 & 50 & 0.01 & 0.5 & ICX & [20] \\
\hline I7 & (points) & 100 & 0 & 50 & 0.01 & 0.5 & ICX & \\
\hline I8 & (points) & 100 & 0 & 50 & 0.01 & 1 & IL & \\
\hline I9 & (points) & 100 & 0 & 50 & 0.01 & 0.5 & ICX & \\
\hline $\mathrm{I} 10$ & (points) & 100 & 0 & 50 & 0.01 & 1 & $\mathrm{IL}$ & \\
\hline I11 & (points) & 100 & 0 & 50 & 0.01 & 0.5 & $\mathrm{DCV}$ & \\
\hline $\mathrm{I} 12$ & (points) & 100 & 0 & 50 & 0.01 & 0.5 & ICX & [54] \\
\hline I13 & (points) & 100 & 0 & 50 & 0.01 & 0.5 & ICX & {$[6,52]$} \\
\hline I14 & (points) & 100 & 0 & 50 & 0.01 & 0.5 & ICX & \\
\hline
\end{tabular}

Legend: DCV—Decreasing Concave; DL—Decreasing Lineal; ICX—Increasing Convex; IL—Increasing Lineal. 
Table A9. Main considerations for the calculations corresponding to each indicator.

\begin{tabular}{cl}
\hline Ix & \multicolumn{1}{c}{ Considerations for These Calculations } \\
\hline I1 & $\begin{array}{l}\text { Cost of: (a) connection composed of metallic screws, washers, knots, plastic connections, twines, } \\
\text { adhesives, (b) substructure with metallic frames, plastic posts ..., (c) mobile system, (d) energy } \\
\text { system and (e) LED or fan. }\end{array}$ \\
\hline I2 & $\begin{array}{l}\text { The disassembling operations for connections among solar control device parts, energy system and } \\
\text { the connected devices. }\end{array}$ \\
\hline I3 & Emissions from the components described in I1. \\
\hline I4 & The surface of the components described in I1 and household waste elements. \\
\hline I5 & The recyclability rate of the waste used in each solar control device. \\
\hline I6 & The color uniformity of the household waste used in each alternative solar control device. \\
\hline I7 & The thermal behavior of each solar control device. \\
\hline I9 & The ventilation behavior of each solar control device and the incorporation of a fan. \\
\hline I10 & The transparency of each solar control device. \\
\hline I11 & The rendering of the household waste, based on each solar control device. \\
\hline I12 & $\begin{array}{l}\text { Flexibility to incorporate children's design \& creativity depending on the type and size of household } \\
\text { waste, whether this waste is paintable and if there is soil for growing plants. }\end{array}$ \\
\hline I13 & $\begin{array}{l}\text { The contribution rate of children's assembly process considering the operation-screw, paint, glue, tie, } \\
\text { cut or plant-, the number of operations depending on the type and size of waste and the percentage of } \\
\text { children operations as part of the total assembly operations. }\end{array}$ \\
\hline Children's feedback regarding use of LED, fan or plants. \\
\hline
\end{tabular}

Table A10. Sustainability indexes.

\begin{tabular}{|c|c|c|c|c|c|}
\hline & Alternatives in Ground Floor Solar Protection Devices (1.1) Fixed (2.1) & $\mathrm{SI}_{\mathrm{R} 1, \mathrm{k}}$ & $\mathrm{SI}_{\mathrm{R} 2, \mathrm{k}}$ & $\mathrm{SI}_{\mathrm{R} 3, \mathrm{k}}$ & $\mathrm{GS}_{\mathrm{k}}$ \\
\hline 1 & Ground floor, fixed, louvres, superficial, PV, fan & 0.89 & 0.72 & 0.82 & 0.81 \\
\hline 2 & Ground floor, fixed, louvres, superficial, PV, LED & 0.89 & 0.72 & 0.78 & 0.78 \\
\hline 3 & Ground floor, fixed, louvres, superficial, WIND, LED & 0.72 & 0.72 & 0.78 & 0.76 \\
\hline 4 & Ground floor, fixed, exterior curtains, bottles, waste + soil, PV, fan & 0.88 & 0.85 & 0.75 & 0.79 \\
\hline 5 & Ground floor, fixed, exterior curtains, bottles, waste + soil, PV, LED & 0.89 & 0.85 & 0.71 & 0.76 \\
\hline 6 & Ground floor, fixed, exterior curtains, bottles, waste + soil, wind, LED & 0.72 & 0.85 & 0.71 & 0.74 \\
\hline 7 & Ground floor, fixed, exterior curtains, other containers, waste + soil, PV, fan & 0.75 & 0.93 & 0.71 & 0.76 \\
\hline 8 & Ground floor, fixed, exterior curtains, other containers, waste + soil, PV, LED & 0.76 & 0.93 & 0.67 & 0.73 \\
\hline 9 & Ground floor, fixed, exterior curtains, other containers, waste + soil, wind, LED & 0.59 & 0.93 & 0.67 & 0.71 \\
\hline 10 & Ground floor, fixed, exterior curtains, superficial, PV, fan & 0.94 & 0.67 & 0.68 & 0.70 \\
\hline 11 & Ground floor, fixed, exterior curtains, superficial, PV, LED & 0.95 & 0.67 & 0.64 & 0.68 \\
\hline 12 & Ground floor, fixed, exterior curtains, superficial, LED & 0.78 & 0.67 & 0.64 & 0.66 \\
\hline 13 & Ground floor, fixed, exterior curtains, small, PV, fan & 0.67 & 0.67 & 0.73 & 0.71 \\
\hline 14 & Ground floor, fixed, exterior curtains, small, PV, LED & 0.67 & 0.67 & 0.69 & 0.68 \\
\hline 15 & Ground floor, fixed, exterior curtains, small, wind, LED & 0.51 & 0.67 & 0.69 & 0.66 \\
\hline 16 & Ground floor, fixed, sun sail, bottle, waste, PV, fan & 0.68 & 0.80 & 0.74 & 0.75 \\
\hline 17 & Ground floor, fixed, sun sail, bottle, waste, PV, LED & 0.68 & 0.80 & 0.70 & 0.72 \\
\hline 18 & Ground floor, fixed, sun sail, other containers, waste, PV, fan & 0.52 & 0.84 & 0.74 & 0.74 \\
\hline 19 & Ground floor, fixed, sun sail, other containers, waste, PV, LED & 0.53 & 0.84 & 0.70 & 0.71 \\
\hline 20 & Ground floor, fixed, sun sail, superficial, PV, fan & 0.86 & 0.64 & 0.67 & 0.68 \\
\hline 21 & Ground floor, fixed, sun sail, superficial, PV, LED & 0.87 & 0.64 & 0.63 & 0.65 \\
\hline 22 & Ground floor, fixed, sun sail, small, PV, fan & 0.37 & 0.55 & 0.73 & 0.65 \\
\hline 23 & Ground floor, fixed, sun sail, small, PV, LED & 0.37 & 0.55 & 0.68 & 0.63 \\
\hline
\end{tabular}


Table A10. Cont.

\begin{tabular}{|c|c|c|c|c|c|}
\hline & Alternatives in the Ground Floor (1.1) that Move (2.2) & $S I_{R 1, k}$ & $\mathrm{SI}_{\mathrm{R} 2, \mathrm{k}}$ & $\mathrm{SI}_{\mathrm{R} 3, \mathrm{k}}$ & $\mathrm{GS}_{\mathrm{k}}$ \\
\hline 24 & Ground floor, movable, louvres, superficial, PV, fan & 0.79 & 0.70 & 0.86 & 0.82 \\
\hline 25 & Ground floor, movable, louvres, superficial, PV, LED & 0.79 & 0.70 & 0.86 & 0.82 \\
\hline 26 & Ground floor, movable, exterior curtains, bottle, waste, PV, fan & 0.78 & 0.83 & 0.82 & 0.82 \\
\hline 27 & Ground floor, movable, exterior curtains, bottle, waste, PV, LED & 0.78 & 0.83 & 0.78 & 0.79 \\
\hline 28 & Ground floor, movable, exterior curtains, other containers, waste, PV, fan & 0.64 & 0.90 & 0.82 & 0.82 \\
\hline 29 & Ground floor, movable, exterior curtains, other containers, waste, PV, LED & 0.64 & 0.91 & 0.77 & 0.79 \\
\hline 30 & Ground floor, movable, exterior curtains, superficial, PV, fan & 0.84 & 0.65 & 0.75 & 0.74 \\
\hline 31 & Ground floor, movable exterior curtains, superficial, PV, LED & 0.84 & 0.65 & 0.71 & 0.71 \\
\hline 32 & Ground floor, movable, exterior curtains, small, PV, fan & 0.56 & 0.65 & 0.80 & 0.75 \\
\hline 33 & Ground floor, movable, exterior curtains, mall, PV, LED & 0.56 & 0.65 & 0.76 & 0.72 \\
\hline 34 & Ground floor, movable, sun sail, bottle, waste, PV, fan & 0.62 & 0.79 & 0.77 & 0.76 \\
\hline 35 & Ground floor, movable, sun sail, bottle, waste, PV, LED & 0.62 & 0.79 & 0.73 & 0.73 \\
\hline 36 & Ground floor, movable, sun sail, other containers, waste, PV, fan & 0.47 & 0.83 & 0.77 & 0.75 \\
\hline 37 & Ground floor, movable, sun sail, other containers, waste, PV, LED & 0.47 & 0.83 & 0.73 & 0.72 \\
\hline 38 & Ground floor, movable, sun sail, superficial, PV, fan & 0.78 & 0.63 & 0.70 & 0.69 \\
\hline 39 & Ground floor, movable, sun sail, superficial, PV, LED & 0.78 & 0.63 & 0.66 & 0.66 \\
\hline 40 & Ground floor, movable, sun sail, small, PV, fan & 0.32 & 0.54 & 0.76 & 0.67 \\
\hline \multirow[t]{2}{*}{41} & Ground floor, movable, sun sail, small, PV, LED & 0.32 & 0.54 & 0.72 & 0.64 \\
\hline & Alternatives from the First Floor on (1.2) Fixed (2.1) & $\mathrm{SI}_{\mathrm{R} 1, \mathrm{k}}$ & $\mathrm{SI}_{\mathrm{R} 2, \mathrm{k}}$ & $\mathrm{SI}_{\mathrm{R} 3, \mathrm{k}}$ & $\mathrm{GS}_{\mathrm{k}}$ \\
\hline 42 & 1st floor on, fixed, louvres, superficial, PV, fan & 0.86 & 0.72 & 0.82 & 0.81 \\
\hline 43 & 1st floor on, fixed, louvres, superficial, PV, LED & 0.86 & 0.72 & 0.78 & 0.78 \\
\hline 44 & 1st floor on, fixed, louvres, superficial, WIND, LED & 0.70 & 0.72 & 0.78 & 0.76 \\
\hline 45 & 1st floor on, fixed, exterior curtains, bottles, waste, PV, fan & 0.79 & 0.85 & 0.74 & 0.76 \\
\hline 46 & 1st floor on, fixed, exterior curtains, bottles, waste, PV, LED & 0.79 & 0.85 & 0.69 & 0.74 \\
\hline 47 & 1st floor on, fixed, exterior curtains, bottles, waste, wind, LED & 0.63 & 0.85 & 0.69 & 0.72 \\
\hline 48 & 1st floor on, fixed, exterior curtains, other containers, waste, PV, fan & 0.57 & 0.93 & 0.70 & 0.73 \\
\hline 49 & 1st floor on, fixed, exterior curtains, other containers, waste, PV, LED & 0.58 & 0.93 & 0.65 & 0.70 \\
\hline 50 & 1st floor on, fixed, exterior curtains, other containers, waste, wind, LED & 0.41 & 0.93 & 0.65 & 0.68 \\
\hline 51 & 1st floor on, fixed, exterior curtains, superficial, PV, fan & 0.90 & 0.67 & 0.68 & 0.70 \\
\hline 52 & 1st floor on, fixed, exterior curtains, superficial, PV, LED & 0.91 & 0.67 & 0.64 & 0.67 \\
\hline 53 & 1st floor on, fixed, exterior curtains, superficial, LED & 0.74 & 0.67 & 0.64 & 0.65 \\
\hline 54 & 1st floor on, fixed, exterior curtains, small, PV, fan & 0.48 & 0.67 & 0.73 & 0.69 \\
\hline 55 & 1st floor on, fixed, exterior curtains, small, PV, LED & 0.49 & 0.67 & 0.68 & 0.66 \\
\hline 56 & 1st floor on, fixed, exterior curtains, small, wind, LED & 0.32 & 0.67 & 0.68 & 0.64 \\
\hline 57 & 1st floor on, fixed, sun sail, bottles, waste, PV, Fan & 0.66 & 0.80 & 0.74 & 0.74 \\
\hline 58 & 1st floor on, fixed, sun sail, bottles, waste, PV, LED & 0.67 & 0.80 & 0.70 & 0.72 \\
\hline 59 & 1st floor on, fixed, sun sail, other containers, waste, PV, fan & 0.50 & 0.84 & 0.74 & 0.73 \\
\hline 60 & 1st floor on, fixed, sun sail, other containers, waste, PV, LED & 0.50 & 0.84 & 0.70 & 0.71 \\
\hline 61 & 1st floor on, fixed, sun sail, superficial, PV, fan & 0.84 & 0.64 & 0.67 & 0.68 \\
\hline 62 & 1st floor on, fixed, sun sail, superficial, PV, LED & 0.84 & 0.64 & 0.63 & 0.65 \\
\hline 63 & 1st floor on, fixed, sun sail, small, PV, fan & 0.21 & 0.55 & 0.73 & 0.64 \\
\hline \multirow[t]{2}{*}{64} & 1st floor on, fixed, sun sail, small, PV, LED & 0.22 & 0.55 & 0.68 & 0.61 \\
\hline & Alternatives from the First Floor on (1.2) that Move (2.2) & $\mathrm{SI}_{\mathrm{R} 1, \mathbf{k}}$ & $\mathrm{SI}_{\mathrm{R} 2, \mathrm{k}}$ & $\mathrm{SI}_{\mathrm{R} 3, \mathrm{k}}$ & $\mathrm{GS}_{\mathrm{k}}$ \\
\hline 65 & 1st floor on, movable, louvres, superficial, PV, fan & 0.76 & 0.70 & 0.86 & 0.82 \\
\hline 66 & 1st floor on, movable louvres, superficial, PV, LED & 0.77 & 0.70 & 0.86 & 0.82 \\
\hline 67 & 1st floor on, movable, exterior curtains, bottle, waste, PV, fan & 0.68 & 0.83 & 0.81 & 0.80 \\
\hline 68 & 1st floor on, movable, exterior curtains, bottle, waste, PV, LED & 0.69 & 0.83 & 0.77 & 0.78 \\
\hline 69 & 1st floor on, movable, exterior curtains, other containers, waste, PV, fan & 0.46 & 0.90 & 0.81 & 0.80 \\
\hline 70 & 1st floor on, movable, exterior curtains, other containers, waste, PV, LED & 0.47 & 0.91 & 0.77 & 0.77 \\
\hline 71 & 1st floor on, movable, exterior curtains, superficial, PV, fan & 0.80 & 0.65 & 0.75 & 0.73 \\
\hline 72 & 1st floor on, movable, exterior curtains, superficial, PV, LED & 0.80 & 0.65 & 0.71 & 0.71 \\
\hline 73 & 1st floor on, movable, exterior curtains, small, PV, fan & 0.40 & 0.66 & 0.80 & 0.73 \\
\hline 74 & 1st floor on, movable, exterior curtains, superficial, PV, LED & 0.40 & 0.66 & 0.76 & 0.70 \\
\hline 75 & 1st floor on, movable, sun sail, bottle, waste, PV, fan & 0.60 & 0.79 & 0.77 & 0.76 \\
\hline 76 & 1st floor on, movable, sun sail, bottle, waste, PV, LED & 0.60 & 0.79 & 0.73 & 0.73 \\
\hline 77 & 1st floor on, movable sun sail, other containers, waste, $\mathrm{PV}$, fan & 0.44 & 0.83 & 0.77 & 0.75 \\
\hline 78 & 1st floor on, movable, sun sail, other containers, waste, PV, LED & 0.44 & 0.83 & 0.73 & 0.72 \\
\hline 79 & 1st floor on, movable, sun sail, superficial, PV, fan & 0.75 & 0.63 & 0.70 & 0.69 \\
\hline 80 & 1st floor on, movable, sun sail, superficial, PV, LED & 0.76 & 0.63 & 0.66 & 0.66 \\
\hline 81 & 1st floor on, movable, sun sail, small, PV, fan & 0.17 & 0.54 & 0.76 & 0.65 \\
\hline 82 & 1st floor on, movable, sun sail, small, PV, LED & 0.17 & 0.54 & 0.71 & 0.63 \\
\hline
\end{tabular}


Table A10. Cont.

\begin{tabular}{|c|c|c|c|c|c|}
\hline & Non-Logical Alternatives & $\mathrm{SI}_{\mathrm{R} 1, \mathrm{k}}$ & $\mathrm{SI}_{\mathrm{R} 2, \mathrm{k}}$ & $\mathrm{SI}_{\mathrm{R} 3, \mathrm{k}}$ & $\mathrm{GS}_{\mathrm{k}}$ \\
\hline 83 & Ground floor, fixed, solid panels, cardboard, PV, fan & 0.94 & 0.33 & 0.70 & 0.65 \\
\hline 84 & Ground floor, fixed, solid panels, cardboard, PV, LED & 0.95 & 0.33 & 0.66 & 0.62 \\
\hline 85 & Ground floor, fixed, solar control glass, superficial, & 0.54 & 0.37 & 0.42 & 0.42 \\
\hline 86 & Ground floor, fixed, solar control glass, plastic bags & 0.54 & 0.30 & 0.47 & 0.44 \\
\hline 87 & Ground floor, movable, roller shutters, superficial, PV, LED & 0.80 & 0.65 & 0.73 & 0.72 \\
\hline 88 & Ground floor, movable, solid panels, cardboard, PV, fan & 0.84 & 0.31 & 0.70 & 0.64 \\
\hline 89 & Ground floor, movable, solid panels, cardboard, PV, LED & 0.85 & 0.31 & 0.66 & 0.61 \\
\hline 90 & 1st floor on, fixed, solid panels, cardboard, PV, fan & 0.93 & 0.33 & 0.70 & 0.65 \\
\hline 91 & 1st floor on, fixed, solid panels, cardboard, PV, LED & 0.94 & 0.33 & 0.65 & 0.62 \\
\hline 92 & 1st floor on, fixed, solar control glass, superficial, & 0.54 & 0.37 & 0.42 & 0.42 \\
\hline 93 & 1st floor on, fixed, solar control glass, plastic bags & 0.54 & 0.30 & 0.47 & 0.44 \\
\hline 94 & 1st floor on, movable, roller shutters, superficial, PV, LED & 0.73 & 0.65 & 0.73 & 0.71 \\
\hline 95 & 1st floor on, movable, solid panels, cardboard, PV, fan & 0.82 & 0.31 & 0.70 & 0.63 \\
\hline \multirow[t]{2}{*}{96} & 1st floor on, movable, solid panels, cardboard, PV, LED & 0.82 & 0.31 & 0.65 & 0.60 \\
\hline & Most Used Current Solar Control Device & $\mathrm{SI}_{\mathrm{R} 1, \mathrm{k}}$ & $\mathrm{SI}_{\mathrm{R} 2, \mathrm{k}}$ & $\mathrm{SI}_{\mathrm{R} 3, \mathrm{k}}$ & \\
\hline 97 & Exterior roller shutter & 0.45 & 0.00 & 0.46 & \\
\hline
\end{tabular}

\section{Appendix E}

Table A11. Abbreviations used in the text.

\begin{tabular}{cc}
\hline Abbreviations & Relevant Values \\
\hline MSW & Municipal Solid Waste \\
AC & Air Conditioning \\
GMA & General Morphology Analysis \\
MCDM & Multi-Criteria Decision Making \\
MIVES & The Integrated Value Model for Sustainable Assessment \\
CCA & Cross-Consistency Assessment \\
AHP & Analytic Hierarchy Process \\
GSk & Global sustainability index \\
SIRi,k & Requirements satisfaction index \\
CIRi,k & Criteria satisfaction index \\
Vi,k & Value from the value function satisfaction \\
LED & Light-Emitting Diodes \\
DCV & Decreasing Concave \\
DL & Decreasing Lineal \\
ICX & Increasing Convex \\
IL & Increasing Lineal \\
PV & Photovoltaic \\
N/A & Not Applicable \\
UA & Unexpected Alternative \\
\hline
\end{tabular}

Table A12. Abbreviations for Equations (1) and (2).

\begin{tabular}{cc}
\hline Abbreviations & Relevant Values \\
\hline $\mathrm{A}$ & The response value to Xmax \\
$\mathrm{ki}$ & Value that comes closer to the ordinate of the curve inflection point \\
$\mathrm{Xalt}$ & Each response to the indicator value function \\
$\mathrm{Xm}=\mathrm{Xmax}$ & The maximum abscissa value considered for decreasing indicators \\
$\mathrm{Xm}=\mathrm{Xmin}$ & The minimum abscissa value considered for increasing indicators \\
$\mathrm{Ci}$ & Value that closer to the abscissa value of the curve inflection point \\
$\mathrm{B}$ & Parameter that maintains the function within the 0 to 1 range \\
\hline
\end{tabular}




\section{References}

1. Moya, D.; Aldás, C.; López, G.; Kaparaju, P. Municipal solid waste as a valuable renewable energy resource: A worldwide opportunity of energy recovery by using Waste-To-Energy Technologies. Energy Procedia 2017, 134, 286-295. [CrossRef]

2. Malinauskaite, J.; Jouhara, H.; Czajczyńska, D.; Stanchev, P.; Katsou, E.; Rostkowski, P.; Thorne, R.J.; Colón, J.; Ponsá, S.; Al-Mansour, F.; et al. Municipal solid waste management and waste-to-energy in the context of a circular economy and energy recycling in Europe. Energy 2017, 141, 2013-2044. [CrossRef]

3. Vani, S.V.S.; Bhaumik, S.; Nandan, A.; Siddiqui, N.A. Hazardous Waste-Impact on health and Environment for sustainable development in India. World Sci. News 2017, 70, 158-172.

4. Chamizo-González, J.; Cano-Montero, E.-I.; Muñoz-Colomina, C.-I. Does funding of waste services follow the polluter pays principle? The case of Spain. J. Clean. Prod. 2018, 183, 1054-1063. [CrossRef]

5. Smith, R. Directive 2008/104/EC of the European Parliament and of the Council of 19 November 2008. In Core EU Legislation; Macmillan Education UK: London, UK, 2015; pp. 426-429, ISBN 978-1-137-54501-5.

6. Reverse Garbage. Reverse Garbage the Experts in reuse. Workshops 2017. Available online: https:/ / reversegarbage.org.au/workshops/ (accessed on 11 October 2017).

7. Wang, Z.; Dong, X.; Yin, J. Antecedents of urban residents' separate collection intentions for household solid waste and their willingness to pay: Evidence from China. J. Clean. Prod. 2018, 173, 256-264. [CrossRef]

8. Fauli, J. The Basilica of the Sagrada Familia; Editorial Palacios y Museos: Madrid, Spain, 2014; ISBN 978-84-8003-665-8.

9. Thomsen, C. Ghost Towns: Lost Cities of the Old West; Bloomsburry Publishing: Oxford, UK, 2012; ISBN 978-0-7478-1085-8.

10. Mansour, A.M.H.; Ali, S.A. Reusing waste plastic bottles as an alternative sustainable building material. Energy Sustain. Dev. 2015, 24, 79-85. [CrossRef]

11. Kovacs, R.; Kommana, Y.; Popiak, A.; Bläsius, T.; Baudisch, P.; Seufert, A.; Wall, L.; Chen, H.-T.; Meinel, F.; Müller, W.; et al. TrussFab: Fabricating Sturdy Large-Scale Structures on Desktop 3D Printers. In Proceedings of the 2017 CHI Conference on Human Factors in Computing Systems (CHI '17), Denver, CO, USA, 6-11 May 2017; pp. 2606-2616.

12. Watson, M. Do-it-Yourself. In International Encyclopedia of Housing and Home; Elsevier: Amsterdam, The Netherlands, 2012; pp. 371-375, ISBN 978-0-08-047163-1.

13. Zomorodian, Z.S.; Tahsildoost, M.; Hafezi, M. Thermal comfort in educational buildings: A review article. Renew. Sustain. Energy Rev. 2016, 59, 895-906. [CrossRef]

14. Michael, A.; Heracleous, C. Assessment of natural lighting performance and visual comfort of educational architecture in Southern Europe: The case of typical educational school premises in Cyprus. Energy Build. 2017, 140, 443-457. [CrossRef]

15. Aumann, D.; Heschong, L.; Wright, R.; Peet, R. Windows and Classrooms: A Study of Student Performance and the Indoor Environment. Available online: https: / www.eceee.org/library/conference_proceedings / ACEEE_buildings/2004/Panel_7/p7_1/ (accessed on 5 November 2018).

16. Barrett, P.; Davies, F.; Zhang, Y.; Barrett, L. The impact of classroom design on pupils' learning: Final results of a holistic, multi-level analysis. Build. Environ. 2015, 89, 118-133. [CrossRef]

17. Martinez-Molina, A.; Boarin, P.; Tort-Ausina, I.; Vivancos, J.-L. Post-occupancy evaluation of a historic primary school in Spain: Comparing PMV, TSV and PD for teachers' and pupils' thermal comfort. Build. Environ. 2017, 117, 248-259. [CrossRef]

18. Pons, O.; Aguado, A. Integrated value model for sustainable assessment applied to technologies used to build schools in Catalonia, Spain. Build. Environ. 2012, 53, 49-58. [CrossRef]

19. AEMet June, Humid and Extremely Warm. Agencia Estatal de Meteorología, 2017. Available online: http:/ / www.aemet.es/en/noticias/2017/07 / Avance_Climatico_junio2017 (accessed on 7 July 2017).

20. Kuhn, T.E. State of the art of advanced solar control devices for buildings. Sol. Energy 2017, 154, 112-133. [CrossRef]

21. De Falco, M.; Capocelli, M.; Losito, G.; Piemonte, V. LCA perspective to assess the environmental impact of a novel PCM-based cold storage unit for the civil air conditioning. J. Clean. Prod. 2017, 165, 697-704. [CrossRef] 
22. Çakirlar Altuntaş, E.; Turan, S.L. Awareness of secondary school students about renewable energy sources. Renew. Energy 2018, 116, 741-748. [CrossRef]

23. Kraaijvangern Architects British Senior School Voorschoten. 2017. Available online: http://www. kraaijvanger.nl/en/projects/753/british-senior-school/ (accessed on 21 July 2017).

24. Comesaña-Campos, A.; Cerqueiro-Pequeño, J.; Bouza-Rodríguez, J.B. The Value Index as a decision support tool applied to a new system for evaluating and selecting design alternatives. Expert Syst. Appl. 2018, 113, 278-300. [CrossRef]

25. Diaz-Sarachaga, J.M.; Jato-Espino, D.; Castro-Fresno, D. Methodology for the development of a new Sustainable Infrastructure Rating System for Developing Countries (SIRSDEC). Environ. Sci. Policy 2017, 69, 65-72. [CrossRef]

26. Álvarez, A.; Ritchey, T. Applications of General Morphological Analysis. Acta Morphol. Gen. 2015, 4, 40.

27. Pons, O.; de la Fuente, A.; Aguado, A. The Use of MIVES as a Sustainability Assessment MCDM Method for Architecture and Civil Engineering Applications. Sustainability 2016, 8, 460. [CrossRef]

28. Cartelle Barros, J.J.; Lara Coira, M.; de la Cruz López, M.P.; del Caño Gochi, A. Sustainability optimisation of shell and tube heat exchanger, using a new integrated methodology. J. Clean. Prod. 2018, 200, 552-567. [CrossRef]

29. Morgan, D.L. Focus Groups as Qualitative Research, 2nd ed.; SAGE: London, UK, 1997; ISBN 978-0-7619-0343-7.

30. Li, Z.; Gómez, J.M. Modeling for Sustainable Product Development Strategies with General Morphological Analysis. Available online: https://www.google.com/url?sa=t\&rct=j\&q=\&esrc=s\&source=web\&cd= 1\&ved=2ahUKEwiq3saa47zeAhUBZlAKHcVCDxwQFjAAegQIBBAC\&url=https\%3A\%2F\%2Fsubs.emis. de\%2FLNI\%2FProceedings\%2FProceedings246\%2F311.pdf\&usg=AOvVaw11G4DQbIQFmK0uu7HqaNjw (accessed on 5 November 2018).

31. Zeiler, W. Morphological Analysis of a Sustainable School Design. In Proceedings of the 18th International Conference on Engineering Design (ICED 11), Lyngby/Copenhagen, Denmark, 15-19 August 2011.

32. Alarcón, B.; Aguado, A.; Manga, R.; Josa, A. A Value Function for Assessing Sustainability: Application to Industrial Buildings. Sustainability 2010, 3, 35-50. [CrossRef]

33. Del Caño, A.; De la Cruz, M.; Gómez, D.; Pérez, M. Fuzzy method for analysing uncertainty in the sustainable design of concrete structures. J. Civ. Eng. Manag. 2016, 22, 924-935. [CrossRef]

34. Büyüközkan, G.; Karabulut, Y. Sustainability performance evaluation: Literature review and future directions. J. Environ. Manag. 2018, 217, 253-267. [CrossRef] [PubMed]

35. Meiboudi, H.; Lahijanian, A.; Shobeiri, S.M.; Jozi, S.A.; Azizinezhad, R. Creating an integrative assessment system for green schools in Iran. J. Clean. Prod. 2016, 119, 236-246. [CrossRef]

36. Saaty, T.L. How to make a decision: The analytic hierarchy process. Eur. J. Oper. Res. 1990, 48, 9-26. [CrossRef]

37. EURONET 50/50 max. Project Reports and Summaries. Available online: http:/ /www.euronet50-50max. eu/en/50-50-library/project-reports-and-summaries (accessed on 5 November 2018).

38. Real Decreto 126/2014, de 28 de Febrero, por el que se Establece el Currículo Básico de la Educación Primaria; Boletín Oficial del Estado: Madrid, Spain, 2014; pp. 19349-19420.

39. Piñero, I.; San-José, J.T.; Rodríguez, P.; Losáñez, M.M. Multi-criteria decision-making for grading the rehabilitation of heritage sites. Application in the historic center of La Habana. J. Cult. Herit. 2017, 26, 144-152. [CrossRef]

40. Reyes, J.P.; San-José, J.T.; Cuadrado, J.; Sancibrian, R. Health \& Safety criteria for determining the sustainable value of construction projects. Saf. Sci. 2014, 62, 221-232. [CrossRef]

41. Ignacio García-Pérez, J.; Hidalgo-Hidalgo, M. No student left behind? Evidence from the Programme for School Guidance in Spain. Econ. Educ. Rev. 2017, 60, 97-111. [CrossRef]

42. Idescat (Catalan Institute of Statistics-Catalan Government). Better Statistics for a Better Society. 2016. Available online: https: / / www.idescat.cat/?lang=en (accessed on 10 November 2017).

43. Analisis estacional. Barcelona, Fabra. Agencia Estatal de Meteorología, 2017. Available online: http:/ / www.aemet.es/es/serviciosclimaticos /vigilancia_clima/analisis_estacional?w=2\&l=0200E\& datos=temp (accessed on 20 October 2017).

44. Ragaert, K.; Delva, L.; Van Geem, K. Mechanical and chemical recycling of solid plastic waste. Waste Manag. 2017, 69, 24-58. [CrossRef] [PubMed] 
45. Zlatanović, L.; van der Hoek, J.P.; Vreeburg, J.H.G. An experimental study on the influence of water stagnation and temperature change on water quality in a full-scale domestic drinking water system. Water Res. 2017, 123, 761-772. [CrossRef] [PubMed]

46. Burke, M.J.; Stephens, J.C. Political power and renewable energy futures: A critical review. Energy Res. Soc. Sci. 2018, 35, 78-93. [CrossRef]

47. Hyder, F.; Sudhakar, K.; Mamat, R. Solar PV tree design: A review. Renew. Sustain. Energy Rev. 2018, 82, 1079-1096. [CrossRef]

48. Nadal, A.; Pons, O.; Cuerva, E.; Rieradevall, J.; Josa, A. Rooftop greenhouses in educational centers: A sustainability assessment of urban agriculture in compact cities. Sci. Total Environ. 2018, 626, 1319-1331. [CrossRef] [PubMed]

49. Pons, O.; Habibi, S.; Peña, D. Towards more sustainable schools incorporating new solar control devices assembled during workshops recycling waste materials. In Advanced Building Skins; Advanced Building Skins GmbH: Bern, Switzerland, 2018; pp. 219-328, ISBN 978-3-9524883-4-8.

50. Piezo Systems Piezoelectric Energy Harvesting Kit. Available online: http://www.piezo.com/ prodproto4EHkit.html (accessed on 12 February 2017).

51. ITEC. ITEC metaBase Banc BEDEC. 2017. Available online: http://metabase.itec.cat/vide/ca/bedec (accessed on 12 February 2017).

52. ADEQ Workshops for Educators. Arkansas Department of Environmental Quality, 2017. Available online: https://www.adeq.state.ar.us/poa/recycling/education/educator_workshops.aspx (accessed on 21 November 2017).

53. LWP Life without Plastic. Available online: https://www.lifewithoutplastic.com/store/common_plastics_ no_1_to_no_7\#.Wj6j7d_iaM9 (accessed on 12 February 2017).

54. Brkovic, M.; Pons, O.; Parnell, R. Where Sustainable School Meets the 'Tthird Teacher': Primary School Case Study From Barcelona, Spain. Int. J. Architect. Res. 2015, 9, 77. [CrossRef]

(C) 2018 by the authors. Licensee MDPI, Basel, Switzerland. This article is an open access article distributed under the terms and conditions of the Creative Commons Attribution (CC BY) license (http:// creativecommons.org/licenses/by/4.0/). 